\title{
Are wild and cultivated flowers served in restaurants or sold by local producers in Denmark safe for the consumer?
}

Egebjerg, Mikael Mandrup; Olesen, Pelle Thonning; Eriksen, Folmer Damsted; Ravn-Haren, Gitte; Bredsdorff, Lea; Pilegaar, Kirsten

Published in:

Food and Chemical Toxicology

Link to article, DOI:

10.1016/j.fct.2018.07.007

Publication date:

2018

Document Version

Peer reviewed version

Link back to DTU Orbit

Citation (APA):

Egebjerg, M. M., Olesen, P. T., Eriksen, F. D., Ravn-Haren, G., Bredsdorff, L., \& Pilegaar, K. (2018). Are wild and cultivated flowers served in restaurants or sold by local producers in Denmark safe for the consumer? Food and Chemical Toxicology, 120, 129-142. https://doi.org/10.1016/j.fct.2018.07.007

\section{General rights}

Copyright and moral rights for the publications made accessible in the public portal are retained by the authors and/or other copyright owners and it is a condition of accessing publications that users recognise and abide by the legal requirements associated with these rights.

- Users may download and print one copy of any publication from the public portal for the purpose of private study or research.

- You may not further distribute the material or use it for any profit-making activity or commercial gain

- You may freely distribute the URL identifying the publication in the public portal 


\section{Accepted Manuscript}

Are wild and cultivated flowers served in restaurants or sold by local producers in Denmark safe for the consumer?

Mikael M. Egebjerg, Pelle T. Olesen, Folmer D. Eriksen, Gitte Ravn-Haren, Lea Bredsdorff, Kirsten Pilegaar

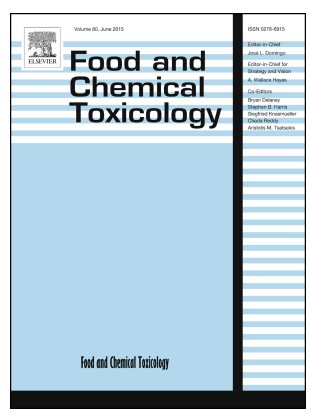

PII: S0278-6915(18)30445-9

DOI: 10.1016/j.fct.2018.07.007

Reference: $\quad$ FCT 9892

To appear in: Food and Chemical Toxicology

Received Date: 2 March 2018

Revised Date: 8 June 2018

Accepted Date: 3 July 2018

Please cite this article as: Egebjerg, M.M., Olesen, P.T., Eriksen, F.D., Ravn-Haren, G., Bredsdorff, L., Pilegaar, K., Are wild and cultivated flowers served in restaurants or sold by local producers in Denmark safe for the consumer?, Food and Chemical Toxicology (2018), doi: 10.1016/j.fct.2018.07.007.

This is a PDF file of an unedited manuscript that has been accepted for publication. As a service to our customers we are providing this early version of the manuscript. The manuscript will undergo copyediting, typesetting, and review of the resulting proof before it is published in its final form. Please note that during the production process errors may be discovered which could affect the content, and all legal disclaimers that apply to the journal pertain. 


\section{Title}

Are wild and cultivated flowers served in restaurants or sold by local producers in Denmark safe for the consumer?

\section{Authors}

Mikael M. Egebjerg ${ }^{\mathrm{a},{ }^{*}}$, Pelle T. Olesen ${ }^{\mathrm{a}}$, Folmer D. Eriksen ${ }^{\mathrm{a}}$, Gitte Ravn-Haren ${ }^{\mathrm{a}}$, Lea Bredsdorff ${ }^{\mathrm{a}}$, Kirsten Pilegaard $^{\mathrm{a}}$.

${ }^{a}$ National Food Institute, Technical University of Denmark

Kemitorvet, Building 201, DK-2800 Kgs Lyngby, Denmark.

*Corresponding author:mmeg@food.dtu.dk

\footnotetext{
${ }^{1}$ Abbreviations:
}

ADI, Acceptable Daily Intake; ARfD, Acute Reference Dose; BAPN, 3-aminopropanenitrile; BfR, The German Federal Institute for Risk Assessment; $\mathrm{BMDL}_{10}$, benchmark dose lower confidence limit 10\%; BVL, German Federal Office of Consumer and Food Safety; bw, body weight; DIBOA, 2,4-dihydroxy-1,4-benzoxazin-3-one; DVFA, Danish Veterinary and Food Administration; EFSA, European Food Safety Authority; EMA, European Medicines Agency; GABA $A_{A}, Y$-aminobutyric acid subtype A receptor; HCN, hydrogen cyanide; IARC, International Agency for Research on Cancer; JECFA, Joint FAO/WHO Expert Committee on Food Additives; L-BOAA, 3[(carboxycarbonyl)amino]alanine; MOAls, monoamine oxidase inhibitors; NOAEL, No Observed Adverse Effect Level; NOEL, No Observed Effect Level; NTP, National Toxicology Program; OPUS, Research project on optimal well-being, development and health for Danish children through a healthy New Nordic Diet; TDI, Tolerable Daily Intake; TMDI, Theoretical Maximum Daily Intake. 


\section{Introduction}

With the introduction of a new cuisine known as New Nordic Food in Denmark and other Nordic countries more than ten years ago there has been an increasing interest in using locally grown food plants and plants collected from the countryside (for detailed information on definition and principles on New Nordic Food, see http://www.newnordicfood.org/). This interest has been driven by highly profiled gourmet restaurants serving New Nordic Cuisine. The movement has been supported by the Nordic Council of Ministers that has assigned leading chefs as New Nordic Food ambassadors aiming at establishing the New Nordic Cuisine as part of the gourmet world map (Mithril et al., 2012; Nordic Council of Ministers, 2017). Additionally, one large Danish research project OPUS (Optimal well-being, development and health for Danish children through a healthy New Nordic Diet; http://foodoflife.ku.dk/opus/english/about/) has studied the impact on a newly developed New Nordic Diet on health. The guidelines developed for this diet did not only focus on local traditionally cultivated plant foods but also recommended inclusion of local wild foods, underlining the possible health potential of e.g. wild plants, mushrooms, berries and fruits, their gastronomic potential and an increased focus on sustainability (Mithril et al., 2012). The idea that wild plants can be collected for food has spread by e.g. cookbook recipes with wild plants, developed smartphone apps and tours arranged by nature guides having the specific purpose of leading interested individuals to areas where wild plants can be collected for culinary purposes.

Other gastronomic arguments for this diet are that foods collected from the wild differ from country to country and are an important part of the identity of a regional cuisine that could give rise to great gastronomic experiences (Mithril et al., 2012). It is, however, also mentioned that the composition of some wild plants is still unknown, some plants may have a high content of bioactive substances, and some plants may be toxic in large quantities (Mithril and Dragsted, 2012; Mithril et al., 2012). Various flowers have been describes as edible decoration on e.g. desserts and cakes, or as ingredients in salads, sometimes constituting a substantial part of the salads. Lately, Danish media and cookbooks have also shown interest in the use of cultivated plants, often known for their traditional ornamental value more than for having been edible. This is not only a Nordic trend. Description of flowers of ornamental plants for human nutrition have e.g. been published by a Czech research group (Mlcek and Rop, 2011; Rop et al., 2012) and reviewed by other groups 
for their nutritional value, flavour and benefits to human health, mostly describing use outside Europe (Fernandes et al., 2017; Ghosh, 2013; Kelley et al., 2001; Lara-Cortes et al., 2013; Lim, 2014).

However, the potential toxic effects of the flowers caused by inherent constituents were not assessed in any of these publications. In addition, potential health concerns arise when eating harvested or purchased ornamental flowers not intended for food use as suggested by Fernandez et al. (2017) including pathogens like Salmonella and addition of unauthorised chemicals as sulphite or pesticides like dimethoate (CAS 60-51$5)$.

A lack of botanical knowledge and the assumption that everything natural possesses no risk is a dangerous cocktail when harvesting wild plants, which in Italy already from the mid-1990s resulted in an increasing number of intoxications mainly due to misidentifications of species (Colombo et al., 2010). In the European Union (EU), novel food is defined as food that has not been consumed to a significant degree by humans in the EU before 15 May 1997' (Regulation (EC) No 258/97). The newest regulation (Regulation (EU) 2015/2283) came into force 1 January 2018. According to the regulation, the determination of whether a food was used for human consumption to a significant degree within the Union before 15 May 1997 should be based on information submitted by food business operators and, where appropriate, supported by other information available in Member States. One of the underlying principles is that novel foods must be safe for the consumers. Whereas it is common to use plant parts like roots/tubers, stems, leaves, fruits and seeds for foods or as spices, blooming flowers have historically rarely been used. Among over 300 major reviewed food plants (Pilegaard et al., 2007), mainly cultivated, used in Europe up to 1997 for which plant parts have been specified, flowers were only mentioned for two species i.e. garden nasturtium (Tropaeolum majus L.) and borage (Borago officinalis L.). Further, it was noted that use of the latter plant might give rise to health concern. Flowers from a few other species were also listed e.g. two species of Tilia L. (lime) but for preparations of infusions and not for eating as such.

From May to October 2016 as part of a control campaign the Danish food authorities (the Danish Veterinary and Food Administration, DVFA) visited 150 restaurants and local producers of e.g. jams, and investigated their use of plants and mushrooms picked from the wild, grown in private gardens or market gardens with special emphasis on the species used aiming at developing a list of plants for which safety and novel food 
status has been clarified as guidance for business operators. It was a general finding that there was a huge interest in using plants and mushrooms from the wild as foodstuffs (DVFA, 2017).

Here, we present a toxicological review of flowers identified in the campaign for food use. The review is based on published information on food use of the flowers before 1997 in addition to published phytochemical analyses and toxicological data of the flowers after intake in humans, farm animals, pets, or experimental animals.

\section{Methods}

The DVFA listed the common Danish and scientific names of the plants, and plant parts used according to information obtained from the campaign when visiting 150 restaurants and local food producers distributed all over Denmark. The plant material was photographed. If there was later doubt about the identity of a reported species, these photos were consulted and the identity of the species was established. Information on the exact food use, including potential preparation of the plants, was not provided to DVFA and therefore not reported in this review. This review is restricted to plants from the campaign for which flowers or inflorescences are used as foodstuffs.

The preferred scientific plant names and commonly used synonyms were substantiated in the botanical databases first in The Plant List (The Plant List 2013. Version 1.1. Published on the Internethttp://www.theplantlist.org/) and additionally in the US National Plant Germplasm System (https://npgsweb.ars-grin.gov/gringlobal/taxon/taxonomysearch.aspx). A plethora of English plant names exist for all the reviewed plant species. The English common names used stem from either the US National Plant Germplasm System or Mansfeld's World Database of Agricultural and Horticultural Crops (https://mansfeld.ipk-gatersleben.de). Danish common names were identified after consulting a botanical textbook with recommended common names (Jensen et al., 2003). It should, however, be kept in mind that compared to a scientific name the vernacular or common name does not uniquely identify the species (Pilegaard et al., 2010).

In the period from February to October, 2017, searches were performed in the bibliographic databases: Web of Science, Scopus, and SciFinder using the preferred scientific name, and if relevant also synonyms. The full scientific papers were obtained if abstracts described ethnobotanical studies on food use in European 
countries (prior to 1997), constituents, especially if toxicological relevant, experimental laboratory animal studies on the toxicological effects of the plants and cases of intoxications in humans or animals exposed to the individual plants. This study focus only on the food use of flowers prior to 15 May 1997, as this is the cutoff date from which a food substance is considered novel, and thus requiring regulation and testing as stipulated by EU regulation 2015/2283. Since the novel food regulation for ordinary food use does not apply for use as flavourings or sole use as ingredients in food supplements, such use of the flowers are not reported in this review. Use only in aqueous extracts as herbal teas/infusions are also considered as out of the scope of this paper as is use as traditional herbal medicine when considering a history of food use. It was checked whether the use of the flowers or inflorescences were mentioned in the Novel Food Catalogue (https://ec.europa.eu/food/safety/novel_food/catalogue_en), a non-exhaustive list, serving as an orientation on whether a plant will need an authorisation under the Novel Food Regulation.

During the review, a number of ethnobotanical surveys on plant use in European countries (Switzerland (Abbet et al., 2014), Cyprus (Della et al., 2006), Czech Republic (Simkova and Polesny, 2015), Poland (Łuczaj, 2008, 2010; Łuczaj and Szymanski, 2007), Spain (Menendez-Baceta et al., 2012), Portugal (Pardode-Santayana et al., 2007), Italy (Passalacqua et al., 2007; Pieroni, 1999), Slovakia (Łuczaj, 2012), Estonia (Sõukand and Kalle, 2016), Sweden (Svanberg, 2012), and the Mediterranean area as a whole (Tardío et al., 2016) were identified and systematically checked for information on use for all reviewed species. Additionally, former plant use in Denmark, including food use, had been thoroughly described in four book volumes (Brøndegaard, 1987).

The review includes data on constituents in the flowers (or other plant parts if toxicological relevant) and cases of intoxications in humans, farm animals or pets after oral intake. Since toxicological information, including animal and human intoxications, is not always reported in scientific papers, toxicological books were also consulted (Cooper and Johnson, 1984; Frohne and Pfänder, 1997; Mølgaard, 2014) together with the homepage of the Danish Poison Centre, Giftlinjen (https://www.bispebjerghospital.dk/giftlinjen/), which provides information about acute effects of ingested plants.

Experimental toxicological data on the flowers are included along with other plant parts, if considered relevant. When estimating a corresponding dose of fresh plant material from a plant extract, the assumption of $10 \%$ extraction yield and $10 \%$ dry weight was used unless specific data were available. Furthermore, in 
some cases where no chemical or toxicological information on the species existed, it is briefly mentioned if other plants within the same genus have given rise to concern for human health. In some cases health based guidance values like Tolerable Daily Intake (TDI) or Acceptable Daily Intake (ADI) for specific constituents in the flowers were identified, and rough estimates (e.g. assuming 100\% absorption after intake) of the amount of plant material that could be ingested before exceeding these values have been made. When exposure data from other food sources are available for a certain compound, this is included in the calculations of safe edible amounts (for an adult, $70 \mathrm{~kg}$ ). Interactions or combined health effects of various constituents in the same plant parts are not considered. If misidentification of the flowering plant with another toxic species has been described in the literature or a database registering Danish plants https://www.fugleognatur.dk/, then the possibility of mistaken identity is also mentioned.

\section{Results}

A total of 23 plants from which flowers or inflorescences are used were identified in the campaign by the DVFA. Risk assessments of the individual flowers following oral intake based on published phytochemical analyses and toxicological data in humans and experimental animals are reported below and summarised in Table 1. In addition, the extent of food use of the flowers prior to 1997 is also reported. No data on toxic effects in farm animals or pets after oral intake of any of the flowers were available. 
Table 1.

\begin{tabular}{|c|c|c|c|c|c|c|}
\hline Family & $\begin{array}{l}\text { Preferred scientific name } \\
\text { (synonyms) }\end{array}$ & English name & Danish name & $\begin{array}{l}\text { Use in Europe } \\
\text { prior to } 1997\end{array}$ & $\begin{array}{c}\text { Phytochemistry of } \\
\text { flowers }\end{array}$ & Toxicological data \\
\hline Amaryllidaceae & Allium schoenoprasum L. & Chives & Purløg & No data available & + & ID \\
\hline \multirow[t]{2}{*}{ Apiaceae } & $\begin{array}{l}\text { Daucus carota L. } \\
\text { (Daucus carota L. ssp. carota) }\end{array}$ & $\begin{array}{l}\text { Wild carrot, } \\
\text { Queen Anne's }\end{array}$ & Vild gulerod & No data available & ++ & ID \\
\hline & Myrrhis odorata (L.) Scop. & Cicely & Sødskærm & No data available & No data available & ID \\
\hline \multirow[t]{2}{*}{ Asteraceae } & Achillea millefolium $\mathrm{L}$. & Yarrow & Almindelig røllike & * & +++ & $\mathrm{TCa} / \mathrm{c}$ \\
\hline & Calendula officinalis L. & Pot marigold & Havemorgenfrue & ** & +++ & $\mathrm{TCc}$ \\
\hline
\end{tabular}


Chrysanthemum coronarium $\mathrm{L}$.

(Glebionis coronaria (L.)

Tzvelev)

Cosmos bipinnatus Cav.

Tagetes tenuifolia Cav.

(Tagetes signata Bartl.)

Boraginaceae

Anchusa officinalis L.

Borago officinalis $\mathrm{L}$.

Almindelig

hjulkrone

\section{Echium vulgare $\mathrm{L}$.}

Brassicaceae

Garland

chrysanthemum

Garden cosmos

Signet marigold

Smalfliget

fløjlsblomst

\section{Viper's bugloss}

Almindelig

Almindelig ægeoksetunge

No data available

No data available

$\mathrm{TCb}$

$\star * *$

$++$

available

$++$

slangehoved

løgkarse
$\mathrm{TCa}$

$\mathrm{TCa}$

ID

\section{$\mathrm{Cb}$}

Cavara \& Grande

(Sisymbrium alliaria (L.) Scop.) 
Lathyrus japonicus Willd.

Beach pea

Strandfladbælg,

No data available

No data available

$\mathrm{TCb}$ strandært

Lamiaceae

Lamium album $\mathrm{L}$.

Døvnælde

$++$

$\mathrm{TCb}$

Lamium galeobdolon (L.)

Yellow archangel

Guldnælde

No data available

Ehrend. \& Polatschek

(Lamiastrum galeobdolon (L.)

Ehrend. \& Polatschek,

Galeobdolon luteum Huds.)

\section{Lamium purpureum $\mathrm{L}$}

Syringa vulgaris L.

Oleaceae

Onagraceae
Epilobium angustifolium L.

Fireweed
Red dead nettle

Lilac

(Chamaenerion angustifolium
Rød tvetand No data available

Almindelig syren

Gederams
No data available

$\mathrm{Ca}$ 
(L.) Scop. , Chamerion

angustifolium (L.) Holub.)

\begin{tabular}{|c|c|c|c|c|c|c|}
\hline Rubiaceae & $\begin{array}{l}\text { Galium odoratum (L.) Scop. } \\
\text { (Asperula odorata L.) }\end{array}$ & Woodruff & $\begin{array}{l}\text { Skovmærke, } \\
\text { bukkar }\end{array}$ & No data available & +++ & $\mathrm{TCa}$ \\
\hline & Galium verum $\mathrm{L}$. & Lady's bedstraw & Gul snerre & No data available & + & ID \\
\hline Tropaeolaceae & Tropaeolum majus $\mathrm{L}$. & $\begin{array}{l}\text { Garden } \\
\text { nasturtium }\end{array}$ & $\begin{array}{l}\text { Blomsterkarse, } \\
\text { tallerkensmækker }\end{array}$ & *** & +++ & $\mathrm{TCa}$ \\
\hline Violaceae & Viola tricolor $\mathrm{L}$. & Heart's ease & Almindelig & * & ++ & $\mathrm{TCa}$ \\
\hline
\end{tabular}

Table 1. Summarized data on use, phytochemistry and toxicology of flowers from the campaign by the Danish food authorities (the Danish Veterinary and Food Administration) May-October 2016, visiting 150 restaurants and local food producers. Use in Europe prior to May 15 1997: * very few data or seldom used, e.g. during famine; ** occasionally used; ${ }^{* * *}$ used. Phytochemical investigations conducted: + very few data; ++ some data available; +++ data available. Toxicological evaluation of oral intake of flowers: ID - insufficient data; TCa - potentially toxic compounds present in flowers; TCb - 
potentially toxic compounds present in other plant parts or related species while data for flowers is inconclusive or absent, TCc - toxicological effects observed in experimental animals or humans due to unidentified toxic compounds. 


\section{$\underline{\text { Amaryllidaceae }}$}

\section{Chives (Allium schoenoprasum L.)}

No data exist on the use of flowers as food in Europe prior to 1997. Organosulphur compounds, including 2,4-dimethylthiophene, 3,4-dimethylthiophene, methyl propyl disulphide and dimethyl trisulphide, have been detected qualitatively in the flowers (Grzeszczuk et al., 2011; Sobolewska et al., 2015). In addition, phenolic compounds have been isolated including gallic acid, coumaric acid, ferulic acid, rutin and other flavonoids, and polyphenolic compounds (Fossen et al., 2000; Kucekova et al., 2013; Lopez-Garcia et al., 2013).

The plant is a cultivated food plant but only the leaves as a spice has a history of use in Denmark as well as other European countries (Brøndegaard, 1987; Pilegaard et al., 2007). Studies providing quantitative data on chemical substances (nitrate, organosulphur compounds, flavonoids, biogenic amines, salicylic acid) in the leaves, aerial parts or essential oils exist (Blekkenhorst et al., 2017; Justesen and Knuthsen, 2001; Kovacs et al., 1999; Kubec et al., 2000; Malakar et al., 2017; Rattanachaikunsopon and Phumkhachorn, 2008)

No data on toxic effects in humans after intake of the flowers of $A$. schoenoprasum and no experimental animal data are available.

Due to lack of phytochemical studies on the flowers, it is not possible to evaluate whether their ingestion will give rise to similar effects as observed with the leaves, and therefore suggesting a substantial equivalence safe for human consumption at this stage would be meaningless. In conclusion, there are insufficient data available in order to establish a safe amount of flowers from $A$. schoenoprasum for human consumption.

\section{$\underline{\text { Apiaceae }}$}

Wild carrot, Queen Anne's lace (Daucus carota L.)

No data exist on use of the inflorescences as food in Europe prior to 1997. The major part of the essential oil consists of monoterpenes ( $\alpha$-pinene, sabinene, myrcene, and $\beta$-bisabolene) (Gonny et al., 2004; Radulovic et al., 2011; Staniszewska and Kula, 2001; Staniszewska et al., 2005). Alkoxy-substituted benzyl derivatives, methyl isoeugenol (9.4\%) and elemicin (4\%), were isolated from the essential oil of inflorescences in one 
study of Corsican D. carota (Gonny et al., 2004); however, three studies did not find alkoxy-substituted benzyl derivatives or only trace amounts (Radulovic et al., 2011; Staniszewska and Kula, 2001; Staniszewska et al., 2005) and thus more data are needed to clarify to what extent these compounds are present in the inflorescences.

No data on toxic effects in humans after intake of the flowers of $D$. carota and no experimental animal data are available. Some alkoxy-substituted benzyl derivatives (e.g. methyl eugenol and elemicin), which are also present in spices, are carcinogenic in experimental animals and have been classified by the International Agency for Research on Cancer (IARC) as group 2B: potential carcinogen to humans. Methyl isoeugenol is not genotoxic (Kobets et al., 2016; Rietjens et al., 2014) and has not been classified by IARC. If the levels of alkoxy-substituted benzyl derivatives in inflorescences of $D$. carota are at the same level or lower than what it found in spices normally used, it may not be considered a heath concern.

Many plants belonging to Apiaceae contains furocoumarins, which are photogenotoxic and carcinogenic (Søborg et al., 1996) but no data are available for inflorescences from D. carota. Polyacetylenes (falcarinol, falcarindiol and falcarindiol 3-acetate) were detected in the root at levels similar to that of commercially sold carrots (Metzger and Barnes, 2009) but no data on their presence in inflorescences are available.

The family Apiaceae contains many edible but also highly poisonous plant species and botanical knowledge is therefore advisable if plants belonging to this family are collected from the wild (Faurholdt et al., 2014; Mølgaard, 2014).

Due to inadequate chemical data, it is not possible to evaluate whether ingestion of the inflorescences give rise to similar intake of constituents as from eating the roots (carrots) from the cultivated plant, and thus may be considered safe due to substantial equivalence. Therefore, it is not possible to establish a safe amount of inflorescences from $D$. carota for human consumption.

Cicely (Myrrhis odorata (L.) Scop.)

No data exist on use of inflorescences as food in Europe prior to 1997 and no phytochemical investigations of the flowers have been conducted. The essential oil from the leaves contains alkoxy-substituted benzyl 
derivatives (anethol, methyl eugenol, and estragole) (Hussain et al., 1990). No data are available on whether M. odorata contains furocoumarins.

No data on toxic effects in humans after intake of the flowers of $M$. odorata and no experimental animal data are available. As described for wild carrot, the family Apiaceae contains many edible but also highly poisonous plant species and botanical knowledge is therefore advisable if plants belonging to this family are collected from the wild (Faurholdt et al., 2014; Mølgaard, 2014).

In conclusion, there are no phytochemical and toxicological data available in order to establish a safe amount of flowers from M. odorata for human consumption.

\section{$\underline{\text { Asteraceae }}$}

Yarrow (Achillea millefolium L.)

The flowering aerial parts have been used in Denmark in the early 1900s in soups (Brøndegaard, 1987) and flowers and stalks are also today in Estonia occasionally eaten by children as a snack (Sõukand and Kalle, 2016). According to the Novel Food Catalogue the food use of the plant is novel in EU, whereas food supplement use of flowers and aerial parts is recognised in EU before 15 May 1997. The essential oil from the flowers contains monoterpenes (1,8-cineole, camphor, $\alpha$ - and $\beta$-thujone, and menthol), sesquiterpene lactones (a-peroxyachifolid, austricine, balchanolide and achillin), and aromatic compounds (azulene and chamazulene) (Bejnarowicz and Smolenski, 1968; Guarrera and Savo, 2016; Hachey et al., 1990; Hausen et al., 1991). Additional studies providing quantitative data on chemical substances (flavonoids, tannins, alkaloids and salicylic acid) in the leaves, aerial parts or essential oils exist (Chandler et al., 1982; Guarrera and Savo, 2016; Ivancheva et al., 2000; Kremers, 1921; Tunon, 1998).

No data on toxic effects after oral intake of the flowers of $A$. millefolium in humans are available.

Experimental data on flowers are available. In mice, exfoliation of immature germ cells, germ cell necrosis, and seminiferous tubule vacuolization were observed when male Swiss albino mice were administered (orally by gavage for 30 days) a hydroalcoholic extract of the flowers of $A$. millefolium at the dose of 300 $\mathrm{mg} / \mathrm{kg}$ bw/day, which corresponds to $20 \mathrm{~g}$ fresh flowers $/ \mathrm{kg}$ bw (based on data in the paper on a yield of 
14.8\%) (Montanari et al., 1998). A study in Wistar rats (Takzare et al., 2011) investigated the effects on testicular tissue when male rats for 22 days were administered an ethanolic extract of the flowers of $A$. millefolium at $800 \mathrm{mg} / \mathrm{kg}$ bw/day (which corresponds to $80 \mathrm{~g}$ fresh flowers $/ \mathrm{kg} \mathrm{bw}$ ). Basal membrane was partially thickened, seminiferous tubules were completely vacuolized, germ cells number was low, and bleeding was observed. Further toxicological studies are needed to elucidate whether intake of the flowers at various doses has toxic effects on the reproductive system. Such effects have not been described for thujone, or any of the other identified compounds, and are therefore likely caused by unidentified toxic compound(s).

Thujone occurs in nature as a variable mixture of $\alpha$-thujone and $\beta$-thujone in various plant parts and the essential oils from a number of plants including absinthe (Artemisia absinthium L.) and sage (Salvia officinalis L.). The neurotoxicity of thujone is well characterized in vitro and in vivo and from cases with severe intoxications in humans after consumption of essential oils rich in thujone or over-dosage of alcoholic A. absinthium preparations (Pelkonen et al., 2013). Thujone ( $\alpha$ - and $\beta-$ ) act as antagonist of the GABA receptor subtype $A\left(G A B A_{A}\right)$ in vitro (Höld et al., 2001; Höld et al., 2000). Based on two earlier subchronic studies in rats cited by the European Commission's Scientific Committee on Food (SCF, 2002), a NOEL (No Observed Effect Level) of thujone was set to $10 \mathrm{mg} / \mathrm{kg}$ bw in males and $5 \mathrm{mg} / \mathrm{kg}$ bw in females at a level where convulsions were not reported. In more recent studies by the National Toxicology Program (NTP), $\alpha$ thujone and an isomeric mixture of $\alpha$ - and $\beta$-thujone were administered to $F 344 / \mathrm{N}$ rats and B6C3F1 mice of both sexes (orally by gavage) (NTP, 2011). In the rat, the NOAEL (No Observed Adverse Effect Level) for mortality and tonic seizures was $12.5 \mathrm{mg} / \mathrm{kg} \mathrm{bw} /$ day (no NOAEL could be established for clonic seizures).

In 2008, the European Council confirmed its limit of $0.1 \mathrm{mg} / \mathrm{kg}$ from 2005 for total thujone ( $\alpha$ - and $\beta$-) in food and beverages and calculated a theoretical maximum daily intake (TMDI) of $0.01 \mathrm{mg} / \mathrm{kg} \mathrm{bw} / \mathrm{day}$. Using the benchmark dose model (benchmark dose lower confidence limit 10\%, $\mathrm{BMDL}_{10}$ ) and an assessment factor of 100, Lachenmeier and Uebelacker (2010) estimated a ADI for thujone at $0.1 \mathrm{mg} / \mathrm{kg}$ bw/day, corresponding to $7.0 \mathrm{mg} /$ day $(70 \mathrm{~kg}$ adult).

Sage is the major source of thujone in food and food ingredients where it is added as flavouring to meat products, ice cream, oils, candy etc. The estimated total mean intake of thujone from food sources in Switzerland was $3.6 \mu \mathrm{g} / \mathrm{kg}$ bw/day (Amberg-Müller, 2007). The fresh flowers of A. millefolium contain 0.37 
$\mathrm{mg}$ thujone/g (based on $1.7 \%(\mathrm{v} / \mathrm{w})$ essential oil with $21.7 \%$ thujone). Using a mean intake of thujone from other sources based on the Swiss data, an intake of more than $18 \mathrm{~g}$ fresh flowers per day (70 kg adult) of $A$. millefolium will exceed the ADI for thujone.

In conclusion, phytochemical data of the plant are available showing a high content of $\alpha$-, and $\beta$-thujone in the essential oil from the flowers. No data are available on toxic effects after intake of the flowers of $A$. millefolium but the toxicity of thujone is well characterised. Further toxicological studies are needed to elucidate whether intake of the flowers has toxic effects on the reproductive system.

Pot marigold (Calendula officinalis L.)

Part of the flowers (ray flowers) are used occasionally in Switzerland as an ingredient in salads (Abbet et al., 2014) and were used in Denmark in salads in the early 1800s (Brøndegaard, 1987). The European Medicines Agency (EMA) has listed ray flowers as a traditional herbal medicine in Europe, however, only for cutaneous use or as a gargle or mouth wash (BVL, 2014; EMA, 2008a, b). Ray flowers contain triterpene saponins, triterpene alcohols, ionone- and sesquiterpene glycosides, carotenoids (primarily lutein and zeaxanthin), coumarins (scopoletin, umbelliferone, asculetin) and polysaccharides (El-Seedi et al., 2017; EMA, 2008b; Olennikov and Kashchenko, 2014; Olennikov et al., 2017). The essential oil from the flowers consists primarily of $\alpha$-cadinol. In addition, smaller amounts were detected of oxalic acid $(0.7 \mathrm{mg} / 100 \mathrm{~g}$ dry weight), quinic acid, malic acid, citric acid and fumaric acid in the air-dried flowers (Miguel et al., 2016).

No data on toxic effects in humans after intake of flowers of $C$. officinalis were identified.

Experimental data are available: The genotoxicity of ethanolic extracts $(60 \%)$ of the flowers was investigated in vitro (Ames test, Aspergillus nidulans and micronucleus tests). The overall conclusion was negative (Ramos et al., 1998). An aqueous extract of flowers and leaves of $C$. officinalis was genotoxic when tested in the Comet assay (Sabir et al., 2015), however, it is not possible to decide whether the effect is caused by the flowers or leaves or a combination of these.

A single dose of an ethanolic extract (70\%) of the flowers showed no acute toxicity when administered orally by gavage to Swiss albino mice at the doses of $0.625,1.25,2.5$ or $5 \mathrm{~g} / \mathrm{kg} \mathrm{bw}$. In a subchronic toxicity study, 
no sign of toxicity was observed when Wistar rats were administered doses of $0.025,0.25,0.5 \mathrm{or} 1 \mathrm{~g} / \mathrm{kg}$ bw/day orally by gavage for 30 days. There were no histopathological findings in heart, kidneys or brain but hepatic inflammation was observed at the highest dose tested (Silva et al., 2007).

In a study in Wistar rats, the acute and subchronic oral toxicity of an aqueous extract of the flowers was investigated. No toxic effects were observed when the extract was administered orally in drinking water at 2 $\mathrm{g} / \mathrm{kg}$ bw (single dose, acute). Increased number of total white blood cells, changes in blood parameters, and slight histopathological changes in the liver were observed in few animals (2/10 in both sexes) at the highest dose of $1 \mathrm{~g} / \mathrm{kg}$ bw/day after 90 days (repeated dose) (Lagarto et al., 2011).

An ethanolic extract $(70 \%)$ of the flowers was administered orally by gavage to Wistar male rats at doses of $0.25,0.5$ or $1 \mathrm{~g} / \mathrm{kg} \mathrm{bw} /$ day for 60 days. At days 53-60, female rats were mated with the male rats, and no toxic effects were observed (bodyweight gain, offspring, and male reproductive toxicological parameters). Female rats were administered the ethanolic extract at the same doses at gestation day 1-6 (preimplantation), 7-14 (organogenesis) or day 15-19 (foetal period). No toxic effects in early and middle periods of pregnancy were reported. Maternal toxicity was observed when the extract was administered at the highest dose during the foetal period of pregnancy (Silva et al., 2009).

In conclusion, the available phytochemical data have not identified constituents of concern. Experimental data suggest no genotoxic or developmental toxic effects but adverse effects on the liver and changes in blood parameters cannot be ruled out based on two studies in rodents with flower extracts for which data did not allow estimation of the corresponding dose of flowers.

\section{Garland chrysanthemum (Chrysanthemum coronarium L.)}

No data exist on use of flowers as food in Europe prior to 1997. Studies have investigated the essential oil of the flowers, which primarily consists of camphor (22-29\%) and cis/trans-chrysantenyl acetate or $\alpha$-pinene (Alvarez-Castellanos et al., 2001; Flamini et al., 2003; Marongiu et al., 2009; Senatore et al., 2004).

No data on toxic effects in humans following oral intake of the flowers of $C$. coronarium and no experimental animal data are available. Pyrethrines have been isolated from another Chrysanthemum species ( $C$. 
cinerariifolium (Trevir.) Vis. (Tanacetum cinerariifolium (Trevir.) Sch.Bip.)) but were not detected in $C$. coronarium (Marongiu et al., 2009).

In the assessment of camphor in flavourings and other food ingredients with flavouring properties (spices containing camphor), the European Food Safety Authority (EFSA) estimated the chronic exposure to 250 $\mu \mathrm{g} / \mathrm{kg}$ bw/day and suggested that maximum limits should be set to ensure that exposure to camphor does not exceed an intake of $2 \mathrm{mg} / \mathrm{kg}$ bw on a single day in any age group (EFSA, 2008a). The content of camphor in the flowers does not give rise to a health concern since an adult $(70 \mathrm{~kg})$ may eat more than $3 \mathrm{~kg}$ fresh flowers (based on $0.13 \%$ essential oil with $29 \%$ camphor) before the maximum limit for acute toxicity of camphor is exceeded.

In conclusion, no safe amount of flowers from $C$. coronarium for human consumption could be established due to limited phytochemical data and insufficient toxicological data.

\section{Garden cosmos (Cosmos bipinnatus Cav.)}

No data exist on use of flowers as food in Europe prior to 1997. Phytochemical investigations of the flowers are limited to a single identification of triterpene alcohols in the flowers (Akihisa et al., 1996). No data exist on toxic effects in humans and no experimental animal data are available.

In conclusion, there are insufficient phytochemical and toxicological data available to establish a safe amount of flowers from C. bipinnatus for human consumption.

Signet marigold (Tagetes tenuifolia Cav.)

No data exist on use of flowers as food in Europe prior to 1997. The essential oil of the flowers contains terpenoids and ketones including dihydrotagetone, tagetone, (Z)-ocimene, $(Z)$-ochimenon and $(E)$-ocimenon. A thiophene ( $\alpha$-terthienyl) (184 mg/kg dry weight) and a carotenoid (lutein) have been isolated from the flowers (Khalil et al., 2012; Marotti et al., 2010). 
No data exist on toxic effects in humans following intake of the flowers of $T$. tenuifolia and no experimental animal data are available.

Acute oral toxicity was observed when a-terthienyl was administered to male rats at a single dose of 200 $\mathrm{mg} / \mathrm{kg}$ bw whereas no effect was observed at $50 \mathrm{mg} / \mathrm{kg}$ bw (16 male rats/group). The toxic effects are not further described (Marles et al., 1995). A subsequent subchronic study by the same research group failed to show any toxic effects (body and organ weight, biochemical and histopathological endpoints) when aterthienyl was administered orally to Wistar rats at $5 \mathrm{mg} / \mathrm{kg}$ bw/day for 28 days. Detailed data from the toxicological study are not presented in the paper (Marles et al., 1995).

In conclusion, there are insufficient phytochemical and toxicological data available to establish a safe amount of flowers from T. tenuifolia for human consumption.

\section{Boraginaceae}

Common bugloss (Anchusa officinalis L.)

No data exist on use of flowers as food in Europe prior to 1997. No phytochemical analysis has been published of the flowers. Lycopsamine, an 1,2-unsaturated pyrrolizidine alkaloid, has been detected in the aerial parts and in seeds (Broch-Due et al., 1980; Pedersen, 1975; These et al., 2013).

No data on toxic effects in humans and no experimental animal data following oral intake of the flowers of $A$. officinalis are available.

Unsaturated pyrrolizidine alkaloids (1,2-unsaturated and their N-oxides) are hepatotoxic, genotoxic, carcinogenic and are causing developmental toxicity in animal studies. In humans, toxic effects after intake of herbal medicine or teas with plants containing 1,2-unsaturated pyrrolizidine alkaloids and outbreaks after intake of contaminated crops have been reported, the latter with mortalities (EFSA, 2011a). Lycopsamine is not genotoxic in vitro in bacteria; however it causes mutations in Drosophila melanogaster and thus is considered potential genotoxic (EFSA, 2011a). When administered to female F344 rats, lycopsamine causes fewer hepatic DNA-adducts when compared to other 1,2-unsaturated pyrrolizidine alkaloids (Xia et al., 2013). 
In conclusion, there are no phytochemical or toxicological data available on the flowers of $A$. officinalis. However a 1,2-unsaturated pyrrolizidine alkaloid, lycopsamine, has been detected in other plant parts that possesses a potential health concern if consumed. Further studies are needed to evaluate whether this or other pyrrolizidine alkaloids are also present in the flowers.

\section{Borage (Borago officinalis L.)}

Flowers have been used in Switzerland and Denmark in salads, as spice, or as a snack (Abbet et al., 2014; Brøndegaard, 1987). In Spain, the flowers were sucked for nectar by children and have been used to decorate salads as early as in the 1700s (Tardío et al., 2016).

Phytochemical analyses of the flowers have focused on pyrrolizidine alkaloids, which are present in the aerial parts of the plant. Thesinine, a saturated pyrrolizidine alkaloid, which are considered non-genotoxic (Ruan et al., 2014), was the only pyrrolizidine alkaloid that was detected in the flowers by Dodson and Stermitz (1986), whereas trace amounts of lycopsamine in the flowers were detected by Avula and coworkers (2015) and quantifiable amounts reported by Cramer and co-workers (2013). Considerable amounts of mostly unknown 1,2-unsaturated pyrrolizidine alkaloids have been detected in the stem spadix $(2,3 \%$ of dry weight) (These et al., 2013).

The essential oil from flowers and leaves contains aldehydes, ketones, alcohols, phenolic compounds, monoterpenes, sesquiterpenes, acetic acid and heptanoic acid (Mhamdi et al., 2009; Saadatian et al., 2017).

No data are available on toxic effects in humans and no experimental animal data following oral intake of the flowers are available. The German Federal Office of Consumer Protection and Food Safety (BVL) lists the plant as List B: 'Substances that are only used in food and for which a dose restriction is required due to certain constituents.' (BVL, 2014).

In conclusion, toxic 1,2-unsaturated pyrrolizidine alkaloids have been detected in the aerial parts of $B$. officinalis and in highly varying degree in the flowers, which possess a potential health concern if the flowers are used for human consumption. 
Viper's bugloss (Echium vulgare L.)

No data exist on use of flowers as food in Europe prior to 1997. Phytochemical analysis of flowers from Germany found 1,2-unsaturated pyrrolizidine alkaloids ( $\mathrm{N}$-oxides primarily) at $2.0 \mathrm{mg} / \mathrm{g}$ whereas analysis of American flowers found $2.1 \mathrm{mg} / \mathrm{g}$ (estimated echimidine equivalents) (Kempf et al., 2010; Mudge et al., 2015). Analysis of two samples of pollen from E. vulgare found $8 \mathrm{mg} / \mathrm{g}$ and $14 \mathrm{mg} / \mathrm{g}$ (estimated lasiocarpine$\mathrm{N}$-oxide equivalents) (Boppré et al., 2005). High concentrations of 1,2-unsaturated pyrrolizidine alkaloids of $13.5 \mathrm{mg} / \mathrm{g}$ (estimated average echimidine equivalents) were detected in pollen from $E$. vulgare from Switzerland while the concentration in nectar was 500 times lower $(25 \mu \mathrm{g} / \mathrm{g})$. A lower content of 1,2unsaturated pyrrolizidine alkaloids of $0.9 \mathrm{mg} / \mathrm{g}$ pollen (retronecine equivalents) was reported by Kempf and co-workers (2010).

No data exist on toxic effects in humans following oral intake of the flowers of E. vulgare and no experimental animal data are available.

In conclusion, due to the presence of toxic 1,2-unsaturated pyrrolizidine alkaloids it possesses a potential health concern if the flowers are used for human consumption.

\section{$\underline{\text { Brassicaceae }}$}

Garlic mustard (Alliaria petiolata (M.Bieb.) Cavara \& Grande)

Flowers were used in $20^{\text {th }}$ century Italy and Bulgaria (Nedelcheva, 2013; Ranfa et al., 2014). No phytochemical analysis of flowers has been conducted. Other plant parts e.g. leaves have a high content of erucic acid (31\%) in the lipid content (0.5\% of dry weight) (Goffman et al., 1999; Guil-Guerrero et al., 1999) and glucosinolates, sinigrin in leaves, and glucotropaeolin (benzyl glucosinolate) in roots were detected. When the plant material is crushed or chewed, glucotropaeolin is metabolized by plant endogenous enzymes to benzyl isothiocyanate, which in A. petiolata can be further metabolized to hydrogen cyanide (HCN) (Frisch et al., 2014), that has been detected in high amounts $(0.1 \mathrm{mg} / \mathrm{g})$ in the fresh leaves (Cipollini and Gruner, 2007). 
No data on toxic effects in humans and no experimental animal data following oral intake of the flowers of $A$. petiolata are available.

EFSA has established a TDI for erucic acid of $7 \mathrm{mg} / \mathrm{kg}$ bw/day (EFSA, 2016b) and an Acute Reference Dose (ARfD) for HCN at $20 \mu \mathrm{g} / \mathrm{kg}$ bw based on human data (EFSA, 2016a). Furthermore, benzyl isothiocyanate has been studied in experimental animal studies.

A subacute oral toxicity study showed decreased body weight gain and food intake when rats were administered benzyl isothiocyanate at doses of 50,100 , or $200 \mathrm{mg} / \mathrm{kg}$ bw/day for 14 days. Haematological changes, peritonitis, and histopathological findings (in the common bile duct, liver, small intestine and lymph nodes) were observed at the highest dose level (Lewerenz et al., 1992). In another study, benzyl isothiocyanate at doses of $12.5-50 \mathrm{mg} / \mathrm{kg}$ bw/day for 14 days did not cause significant pre- and postimplantation foetal loss in pregnant rats but induced low foetal and placental weights that could be of obstetrical importance (Adebiyi et al., 2004).

In conclusion, since no data on the potential contents of erucic acid, HCN and benzyl isothiocyanate in the flowers of $A$. petiolata are available, it is not possible to compare the intake of these toxic substances from the flowers with the health based guidance values.

\section{Fabaceae}

Common broom (Cytisus scoparius (L.) Link)

No data exist on use of flowers as food in Europe prior to 1997 . Quinolizidine alkaloids ( $0.21 \%$ of wet weight) and tyramine $(0.13 \%$ of wet weight) have been detected in flowers (Murakoshi et al., 1986). Phytochemical analysis of the flowers showed an average total quinolizidine alkaloid content between $299-610 \mu \mathrm{g} / \mathrm{g}$ dry weight (with samples as high as $801 \mu \mathrm{g} / \mathrm{g}$ dry weight) whereas the average total tyramine content was between $643-1657 \mu \mathrm{g} / \mathrm{g}$ dry weight (with samples as high as $2783 \mu \mathrm{g} / \mathrm{g}$ dry weight) (Gresser et al., 1996). Sparteine was the major quinolizidine alkaloid (<98\%) with 11,12-dehydroxysparteine, lupanine, 17oxosparteine, and 13a-hydroxylupaine in smaller amounts. Lectins and isoflavones have been detected in 
other plant parts (Bird and Wingham, 1980; Cunha et al., 2012; Konami et al., 1992; Young et al., 1984) but the flowers have not been investigated.

The plant is listed among toxic plants in botanical handbooks (Cooper and Johnson, 1984; Frohne and Pfänder, 1997; Mølgaard, 2014) but no recent toxic effects after oral intake of the flowers have been described. BVL lists all plant parts of $C$. scoparius on List A: 'Substances not recommended for use in foods due to known risks' (BVL, 2014).

The toxicity of quinolizidine alkaloids has been studied in seeds of Lupinus species. Acute oral toxic effects include nausea, vomiting, sweating, mydriasis, visual disturbance, ataxia, ventricular extrasystole, respiratory arrest, unconsciousness and dead. Mortalities in children have been reported after intake of 11-25 $\mathrm{mg}$ total quinolizidine alkaloids/kg bw (Cheeke, 1989; Pilegaard and Gry, 2008)

Sparteine was previously used as an approved drug for the treatment of cardiac arrhythmias and to induce labour at $150 \mathrm{mg}$, intramuscular, but is now replaced by other products. Nine percent of the white English population are poor metabolizers of sparteine (Galloway et al., 1992).

Tyramine, which occurs in many plants and in fermented foods, may cause hypertension, headache, mydriasis, and sweating following high intake (EFSA, 2011b). The symptoms are reversible and normally disappear after hours or within a day. Due to insufficient data, EFSA was not able to calculate a NOAEL but no toxic effects were observed in healthy adults after intake of $600 \mathrm{mg}$ tyramine from a single meal. Treatment with monoamine oxidase inhibitors (MOAIs) increased the sensitivity to tyramine (EFSA, 2011b).

Other toxic plants including European gorse (Ulex europaeus L.) and Genista species (that is somewhat confusing also often called broom in English) may be mistaken for C. scoparius (Mølgaard, 2014).

In conclusion, the use of the flowers of $C$. scoparius for human consumption possesses a potential health concern due to presence of toxic compounds.

Beach pea (Lathyrus japonicus Willd.) 
No data exist on use of flowers as food in Europe prior to 1997. No phytochemical analysis of the flowers of L. japonicus are available but other members of the Lathyrus genus contain toxic amino acids including 3[(carboxycarbonyl)amino]-L-alanine (also known as L-BOAA or ODAP) and 3-aminopropanenitrile (BAPN). Phytochemical analysis of a subspecies L. japonicus ssp. maritimus (L.) P.W.Ball showed L-BOAA in mixed mature and immature seeds ( $4 \mathrm{mg} / 100 \mathrm{~g}$ dry weight), in fresh green seeds ( $2.9 \mathrm{mg} / 100 \mathrm{~g}$ dry weight) and in stems (0.7 mg/100 g dry weight) (Chavan et al., 2003). Flowers were not studied.

No data on toxic effects in humans following intake of the flowers of $L$. japonicus and no experimental animal data on the flowers are available.

L-BOAA is a neurotoxin causing motor neuron degeneration (lathyrism). BAPN causes bone deformity including epiphyseal plate lesions, degenerative arthritis (osteolathyrism) and aneurysm of the aorta (angiolathyrism) in animal studies (Wawzonek et al., 1955), and causes effects on collagen metabolism in clinical studies (Keiser and Sjoerdsma, 1967).

Epidemics of neurolathyrism following intake of L. sativus have been reported in Europe and Asia in the 181900s during famine e.g. The Spanish Civil War (Gimenez-Roldan and Spencer, 2016), in a labour camp during World War II (Cohn and Streifler, 1983), and in Ethiopia 1976-77 and 1995-97 (Getahun et al., 1999). Clinical signs appear 3-6 months after ingestion of a diet containing at least $400-500 \mathrm{~g}$ of the seeds of $L$. sativus, which contains L-BOAA and BAPN. Neurolathyrism, osteolathyrism and angiolathyrism have been reported after intake of large amounts of L. sativus in Bangladesh (Haque et al., 1997).

In conclusion, although no phytochemical data or toxicological data on the flowers of $L$. japonicus exists, data from other plant parts from a subspecies and from other Lathyrus species show a presence of toxic amino acids and thus the flowers possess a potential health concern if used as food for human consumption.

\section{$\underline{\text { Lamiaceae }}$}

White dead nettle (Lamium album L.)

Flowers were used as a snack during agricultural work in Switzerland, by kids in Estonia and have been used in local Mediterranean dishes together with leaves and shoots (Abbet et al., 2014; Sõukand and Kalle, 
2016; Yordanova et al., 2014). A children amusement of sucking drops of nectar from the bases of the flowers of L. album is described (Brøndegaard, 1987; Łuczaj, 2008; Simkova and Polesny, 2015; Sõukand and Kalle, 2016; Svanberg, 2012). Various alkanes, ketones, alcohols and terpenes have been detected in the essential oil from the flowers (Alipieva et al., 2003; Morteza-Semnani et al., 2016). Iridoid glycosides have been detected in the aerial parts or whole plant (Alipieva et al., 2007; Alipieva et al., 2006; Damtoft, 1992) but the flowers have not been analysed. In the aerial parts (a mixture of flowers, leaves and stems) verbascoside and isoverbascoside accounted for 55\% of the quantified phenols (Pereira et al., 2012). Phytoecdysteroids have been detected in the flowers (Budzianowski and Skrzypczak, 1995; Pereira et al., 2012; Savchenko et al., 2001),

Verbascoside showed increased chromosome aberrations and sister chromatid exchanges in vitro in human lymphocytes cultures. However, the results may be due to instability and breakdown of verbascoside to caffeic acid and 3,4-dihydroxyphenyl ethanol in test media (Santoro et al., 2008) (caffeic acid is classified by IARC as 2B: possibly carcinogenic to humans, based on animal studies (IARC, 1993)). Verbascoside was not genotoxic in vivo in two strains of Drosophila melanogaster but the results may be due to low absorption from the gut of the compound (Santos-Cruz et al., 2012).

BVL lists the plant as List B: 'Substances that are only used in food and for which a dose restriction is required due to certain constituents' (BVL, 2014). BLV recognizes the use of the plant for infusions but not for ordinary food use.

No data exist on toxic effects in humans after oral intake of flowers of $L$. album and no experimental animal data are available.

In conclusion, further studies are needed to establish whether verbascoside is present in the flowers, and whether the substance is genotoxic before a safe amount can be established for human consumption.

Yellow archangel (Lamium galeobdolon (L.) L.)

No data exist on use of flowers as food in Europe prior to 1997. From Spain, a children amusement of sucking drops of nectar from the bases of the flowers of L. galeobdolon is described (Menendez-Baceta et 
al., 2012). A benzoxazinoid 2,4-dihydroxy-1,4-benzoxazin-3-one (DIBOA) concentration of $5 \mathrm{mmol} / \mathrm{kg}$ wet weight was detected in flowers and $7.7 \mathrm{mmol} / \mathrm{kg}$ wet weight in flower buds (Schullehner et al., 2008). From the aerial parts DIBOA and four benzoxazinoid glycosides (blepharin, 6-hydroxy blepharin, 7-hydroxy blepharin and DIBOA glycoside) have been isolated (Alipieva et al., 2003). Other identified compounds from the aerial parts include iridoid glycosides (Alipieva et al., 2006; Bianco et al., 1986) and a phenolic glycoside (Nikolova and Asenov, 2006). Phytoecdysteroids were detected in the seeds but no information of the flowers is available (Savchenko et al., 2001).

No data on toxic effects in humans after oral intake of flowers of $L$. galeobdolon and no experimental animal data are available.

DIBOA has been tested in various genotoxicity tests. In a screening for in vitro genotoxicity using a bacterial reverse mutation test, though limited to Salmonella typhimurium tester strains TA100 and TA98, DIBOA was positive (Hashimoto et al., 1979). DIBOA was genotoxic in S. typhimurium TA100 (with and without added metabolic activation) and in TA98 (with metabolic activation) to a minor extent. When the test was repeated (Buchmann et al., 2007), DIBOA was again found to be genotoxic in TA100 (dose dependently, with and without metabolic activation) but only genotoxic at the highest concentrations in TA98 and in another $S$. typhimurium strain, YG1024. The concentration of DIBOA resulting in genotoxic effects was high compared to known high-potent genotoxic compounds. DIBOA showed no effect in a Comet assay whereas a micronucleus test showed that the substance caused an increased number of micronuclei due to an aneugenic mechanism (evaluated by a fluorescence in situ hybridization (FISH) technique) (Buchmann et al., 2007).

In conclusion, the presence of DIBOA suggests that the use of the flowers of $L$. galeobdolon for food possess a potential health concern.

Red dead nettle (Lamium purpureum L.)

No data exist on use of flowers as food in Europe prior to 1997. The essential oil from the flowers contain esters, terpenes (squalene) and 2,4-dichloro-1-methyl benzene (Alipieva et al., 2003). No other chemical analysis of the flowers was identified. Reported constituents in other plant parts (the aerial parts) were: 
iridoid glycosides (lamiol, lamioside, 5-deoxylamiol, lamalbide, barlerine, caryoptside and shanzhisid methyl ester) (Alipieva et al., 2003; Alipieva et al., 2007; Ito et al., 2006; Yalçin et al., 2008), phytoecdysteroids (20hydroxyecdysone and 24-epi-pterosterone) and phenolic compounds (verbascoside, isoverbascoside, leucoseptoside A, trans-lamiuside E and lamiuside A, B, C, D, and E) (Alipieva et al., 2003; Ito et al., 2006; Savchenko et al., 2001).

No data on toxic effects in humans after oral intake of flowers, and no experimental animal data are available.

In conclusion, it is not possible to establish a safe amount of flowers for human consumption based on the limited data.

\section{$\underline{\text { Oleaceae }}$}

\section{Lilac (Syringa vulgaris L.)}

No data exist on use of flowers as food in Europe prior to 1997. The essential oil from the flowers contains 1,8-cineole (eucalyptol) (0.2-7.5 \% of total essential oil) (Oh et al., 2008). Verbascoside (2.5\% of dry weight) and echinacoside $(0.8 \%$ of dry weight) have been isolated from the flowers in addition to oleuropein ( $1 \%$ of dry weight) (Toth et al., 2016).

No data are available on toxic effects in humans after oral intake of the flowers of $S$. vulgaris.

Studies testing the genotoxicity of verbascoside have already been described under Lamium album L.

Two studies in Wistar rats showed no toxic effects when an ethanol tincture (flowers-ethanol, 1:5) was administered orally by gavage either as a single dose or once daily for 14 days (Berbecaru-lovan et al., 2016; Berbecaru-lovan et al., 2014). The scientific value of these studies is limited: Endpoints were behaviour and acute toxicity but no information was available on doses, number or sex of animals per dose and no autopsy was performed.

In conclusion, due to the few phytochemical data and the limited value of the experimental studies performed, it is not possible to establish a safe amount of flowers for human consumption. 


\section{$\underline{\text { Onagraceae }}$}

\section{Fireweed (Epilobium angustifolium L.)}

The plant is listed among species from which flowers and other plant parts like leaves have been used as emergency bread additives in the 1800s Sweden (Svanberg, 2012). Other plant parts including inflorescences have been used by Baltic Germans in the 1800s (Sõukand and Kalle, 2016). No other data on use of flowers as food in Europe prior to 1997 were identified. The plant (herb and flower) is listed as a traditional herbal medicine in Europe (EMA, 2015).

The flowers and leaves contain polyphenolic compounds (150-200 mg/g dry weight flowers and leaves), which primarily consists of ellagitannins (90\%) (Baert et al., 2017; Hiermann and Radl, 1998). Lectins have been detected in the flowers (Abudayeh et al., 2016).

No data are available on toxic effects in humans after oral intake of flowers of $E$. angustifolium.

Lectins are potential acute oral toxic unless heat-inactivated (e.g. by cooking). However, no data suggest oral toxicity of the lectins in E. angustifolium.

No experimental studies with the flowers were identified but other plant parts have been investigated. No toxic effects were observed (hepatic enzymes, histopathological endpoints in liver, kidneys, thymus and spleen) when male Wistar rats were administered $1.5 \mathrm{ml}$ of an ethanolic extract of stem, leaves and flowers orally by gavage for 10 days (Roman et al., 2010). Anti-androgenic effects (reduced weight of vesicular seminalis) and pro-androgenic effects (increased weight of prostate and musculus laevator ani) were observed in male Wistar rats that were dosed orally by gavage with $40 \mathrm{mg} / \mathrm{kg}$ bw/day (corresponding to a dose of $400 \mathrm{mg}$ fresh plant material/kg bw/day) of an aqueous extract of the aerial parts for 20 days (Hiermann and Bucar, 1997). The number of animals was not reported.

In conclusion, since the flowers have not been studied in experimental animal studies, it is not possible to evaluate whether the effects on the reproductive system observed with the aerial parts when administered to rats also applies to the flowers. Thus, it is not possible to establish a safe amount of the flowers for human consumption. 


\section{$\underline{\text { Rubiaceae }}$}

Woodruff (Galium odoratum (L.) Scop.)

No data exist on use of flowers as food in Europe prior to 1997. The essential oil from the plant contains high levels of coumarin (up to $1 \%$ of dry weight in the leaves, less in the flowers) and smaller amounts of thymol, a-thujone, and other monoterpenes (Laub and Olszowski, 1982; Lim, 2014; Martin and Bodson, 2010).

No data on toxic effects in humans following intake of the flowers of G. odoratum and no experimental data are available. BVL lists the plant as List B: 'Substances that are only used in food and for which a dose restriction is required due to certain constituents' (BVL, 2014).

Coumarin was used as an approved drug in the 1970s, but adverse effects (hepatotoxicity) caused the drug to be retracted in the 1990s (Andrejak et al., 1998; Cox et al., 1989; Loprinzi et al., 1997; WHO, 1995). Clinical trials indicate that a subgroup of the population show coumarin-induced hepatotoxicity probably due to an immune mechanism (Abraham et al., 2010). EFSA estimated a TDI based on animal studies for coumarin at $0.1 \mathrm{mg} / \mathrm{kg}$ bw/day, which was confirmed by the German Federal Institute for Risk Assessment (BfR) based on human data (BfR, 2006b; EFSA, 2004). EFSA later also added that intake of up to 3 times TDI for 1-2 weeks are of no health concern (EFSA, 2008b). A total daily exposure of coumarin of $0.27 \mathrm{mg} / \mathrm{kg}$ bw was estimated for 2-5 year-old children, the group with the highest exposure (BfR, 2006a). There are no corresponding data for adults. Intake of more than $7 \mathrm{~g}$ fresh flowers of $\mathrm{G}$. odoratum by a $70 \mathrm{~kg}$ adult (based on $1 \%$ coumarin) will exceed TDI for coumarin.

In conclusion, $7 \mathrm{~g}$ of fresh flowers of $\mathrm{G}$. odoratum is considered a safe amount of flowers for human consumption.

Lady's bedstraw (Galium verum L.)

Early literature suggest that the flowers were used in 1600-1700s Denmark to coagulate milk in cheese manufacture (Brøndegaard, 1987). A more recent food use of flowers closer to 1997 was not identified. 
Terpenes (squalene, 20.8\%), alcohols (cis-3-hexen-1-ol, 29.8\%) and fatty acids have been isolated from the essential oil of the flowers (Il'ina et al., 2009).

No data on toxic effects in humans and no experimental data are available.

In conclusion, it is not possible to establish a safe amount of flowers from G. verum for human consumption.

\section{$\underline{\text { Tropaeolaceae }}$}

Garden nasturtium (Tropaeolum majus L.)

Flowers have been used as food or food ingredients in Europe since the 1600s (Friedman et al., 2005; Phillips, 1822). Ethnobotanical studies describe the use of the flowers for flavouring or for decoration of food e.g. in salads in 1800-1900s Switzerland, Denmark and Estonia (Abbet et al., 2014; Brøndegaard, 1987; Sõukand and Kalle, 2016). The flowers contain a large amount of fatty acids (36\% of dry weight) with erucic acid as the major component (34.5\% of the fatty acids) (Radwan, 1976) corresponding to $12.4 \%$ of dry weight. In addition, high levels of glucosinolates have been detected in the flowers, including glucotropaeolin (4 mg/g wet weight) (Lykkesfeldt and Moller, 1993).

No data on toxic effects are available. Seventeen cases with children eating unspecified amounts of flowers, leaves, or seeds showed no acute toxic effects (Frohne and Pfänder, 1997).

No experimental data on the flowers are available. Extracts (aqueous and $70 \%$ ethanolic) of the leaves have been tested for acute oral toxicity and failed to show toxic effects when administered to Wistar rats or mice (strain not stated), orally by gavage at doses up to $5 \mathrm{~g} / \mathrm{kg}$ bw (Gasparotto et al., 2009; Zanetti et al., 2003). A 28-day repeated dose toxicity study in rats showed no toxic effects (body weight gain, organ weight, clinical parameters and histopathology) when an ethanolic (70\%) extract of the leaves were administered orally by gavage at doses of 75,375 or $750 \mathrm{mg} / \mathrm{kg}$ bw/day (Gomes et al., 2012).

The potential reproductive toxicity of extracts of the leaves of $T$. majus was investigated by Lourenço and coworkers (2012). A screening for oestrogenic and antiandrogenic effects in Wistar rats after administration (orally by gavage) of an ethanolic (90\%) leaf extract at the doses of 3,30 or $300 \mathrm{mg} / \mathrm{kg} \mathrm{bw} /$ day for 3 or 7 
days (for oestrogen/antioestrogen effects and antiandrogen effects, respectively) showed no effect, however when pregnant Wistar rats in a subsequent study received the same dose regime elevated levels of dehydroepiandrosterone were observed (at the doses of 30 or $300 \mathrm{mg} / \mathrm{kg}$ bw/day) in addition to elevated levels of oestradiol at the highest dose level ( $300 \mathrm{mg} / \mathrm{kg} \mathrm{bw} /$ day) and increased pre-implantation losses at all dose levels (Lourenço et al., 2014). A more recent study (Lourenço et al., 2017) showed fetopathies when Wistar rats received the same dose regime $(3,30$ or $300 \mathrm{mg} / \mathrm{kg}$ bw/day) for 20 days, however, due to methodical flaws (wrong use of statistical analysis, no histological staining to confirm apoptotic findings etc.) the results have limited scientific value. The dose regime corresponds to $0.19,1.9$ and $19 \mathrm{~g}$ fresh leaves $/ \mathrm{kg}$ bw/day based on yield of $16 \%$.

With an estimated TDI for erucic acid of $7 \mathrm{mg} / \mathrm{kg}$ bw/day based on myocardial lipidosis as the critical effect, and a total mean intake of erucic acid from other food sources in Europe of $1 \mathrm{mg} / \mathrm{kg} \mathrm{bw} /$ day (adult, $3.8 \mathrm{mg} / \mathrm{kg}$ bw/day for the 95th-percentile) (EFSA, 2016b), intake of more than $39.5 \mathrm{~g}$ fresh flowers of $T$. majus will exceed the TDI for erucic acid.

Glucotropaeolin is metabolized to benzyl isothiocyanate by plant endogenous enzymes. In the mentioned toxicological studies of benzyl isothiocyanate (Adebiyi et al., 2004; Lewerenz et al., 1992) (see under garlic mustard (Alliaria petiolata), the dose (200 mg/kg bw/day) which caused haematological and histopathological changes (Lewerenz et al., 1992) corresponds to a dose of $50 \mathrm{~g}$ fresh flowers $T$. majus $/ \mathrm{kg} \mathrm{bw} / \mathrm{day}$. The doses of benzyl isothiocyanate (12.5-50 $\mathrm{mg} / \mathrm{kg}$ bw/day for 14 days) that induced low foetal and placental weights (Adebiyi et al., 2004) correspond to $3.1,6.3$ and $12.5 \mathrm{~g}$ fresh flowers of $T$. majus $/ \mathrm{kg}$ bw/day. These calculations are based on $4 \mathrm{mg} / \mathrm{g}$ wet weight (Lykkesfeldt and Moller, 1993) and under the assumption that all glucotropaeolin is converted to benzyl isothiocyanate. No TDI for glucotropaeolin is available.

In conclusion, since the flowers have not been thoroughly chemically studied it is not possible to evaluate whether the ingestion of the flowers gives rise to similar intake of constituents as from eating the leaves. Thus more studies are needed to establish whether the potential effect on reproduction reported for the leaves also applies for the flowers.

$\underline{\text { Violaceae }}$ 
Heart's ease (Viola tricolor L.)

Flowers are used in Switzerland in salads (Abbet et al., 2014). The plant (herb and flower) is listed as a traditional herbal medicine in Europe (EMA, 2010a). The aerial parts including flowers contain a high amount of salicylic acid and derivatives including methyl salicylate (EMA, 2010b).

No data on toxic effects in humans and no experimental data are available after intake of $V$. tricolor, however, in a case from Iran haemolytic anaemia in a 9-month old infant was reported following intake of an extract from V. tricolor. The condition was due to the hereditary abnormality G6DP (glucose-6-phosphatedehydrogenase deficiency) (Behmanesh and Abdollahi, 2002).

Methyl salicylate is metabolized to salicylic acid (Davison et al., 1961). Subgroups of the population are salicylic acid sensitive (e.g. 10-20\% of asthmatic patients) (Malakar, 2017). JECFA (Joint FAO/WHO Expert Committee on Food Additives) set an ADI for methyl salicylate at $0.5 \mathrm{mg} / \mathrm{kg}$ bw/day (JECFA, 2002) based on a NOAEL from chronic toxicity studies in rats, dogs and rabbits (Webb and Hansen, 1963). Since data on the content of methyl salicylate in the flowers are lacking, an estimation of the amount of fresh flower that can be ingested before the ADI for methyl salicylate is exceeded cannot be performed.

BVL lists the plant as List B: 'Substances that are only used in food and for which a dose restriction is required due to certain constituents' (BVL, 2014).

In conclusion, the flowers of $V$. tricolor contain high levels of methyl salicylic which may present a health concern for subgroups of the population. 


\section{Discussion}

\subsection{Ethnobotanical surveys and more recent use of flowers}

The emerging trend of foraging wild plants is not only restricted to restaurants and local food producers in the Nordic countries. Other top European restaurants include plants collected from the wild or ornamental plants in their kitchen (Łuczaj et al., 2012). In fact, the historical and cultural value of wild plant food species in Southern Europe appears to be much more common compared to that of Central and Northern Europe, both regarding the number of taxa used and the extent of historical use (Łuczaj and Szymanski, 2007; Svanberg, 2012; Svanberg and Ægisson, 2012).

Ethnobotanical studies report that consumption of flowers was especially common among children and shepherds as snacks but that people considered it more a children amusement than a feeding behaviour (Menendez-Baceta et al., 2012 ; Pardo-de-Santayana et al., 2007), thus the data on the amount consumed and the extent of use are sparse. The only reported use of e.g. yellow archangel (Lamium galeobdolon (L.) L.) described was children sucking nectar from the flowers. In fact, in a botanical review of 97 wild edible plants in Portugal, flowers from eight species were reported as traditionally used but only in preparation of liqueur, herbal teas or sucking of flowers for nectar (Pardo-de-Santayana et al., 2007).

\subsection{Toxicological studies}

Only few papers have previously focused on the safety of newly introduced plant foods. Within the remit of the Danish research project OPUS, the safety of four commonly found wild plant species used as leaf vegetables was evaluated using a substantial equivalence approach comparing the levels of different potential toxic constituents within the studied plants with the levels of the same constituents found in wellknown food plants. If the exposure levels of the different constituents, compared one by one, were equal or lower than the levels found in commonly used food plants, the new plant was presumed to be safe (Mithril and Dragsted, 2012). A prerequisite for using this approach is the existence of well-performed chemical studies focusing on all potential harmful substances in the plants under study and that the isolated substances are already found in commonly ingested food plants for comparison. This is not the case for most of the flowers in our review where lack of, or inadequate phytochemical data of the flowers were common findings. Since funding for chemical analysis are limited, they seem to be directed towards already 
used plant parts as shown for chives (Allium schoenoprasum) where data exist on the sulphurous substances in the normally used leaves whereas they are non-existent for flowers, a plant part not commonly eaten. Furthermore, focusing only on the identified constituents in a plant part may overlook toxic effects caused by substances not yet identified in the plants or toxic effects not yet ascribed to a substance e.g., for yarrow (Achillea millefolium) where testing of extracts of the flowers had an effect on testicular tissue in mice and rats that cannot be ascribed to the content of thujone. Additionally, toxic effects caused by different constituents in combination may be overlooked.

No well-conducted experimental toxicological studies with any of the flowers were identified. Sometimes flower extracts were studied but data did not allow calculation of the corresponding dose of fresh or dried flower e.g. for pot marigold (Calendula officinalis), where slight histological changes in the liver were observed at the highest dose in one study.

\subsection{Toxic amounts}

Some of the reviewed flowers contained constituents e.g. HCN, erucic acid, coumarin or thujone for which health based guidance values like TDI or ADI have been set by EFSA or JECFA. In some cases, it was possible to make a rough estimate (e.g. assuming $100 \%$ absorption of the substance from the flower) of the amount of plant material that may be eaten before a guidance value was exceeded. It was estimated that intake of more than $39.5 \mathrm{~g}$ fresh flowers of garden nasturtium (Tropaeolum majus) will exceed the TDI for erucic acid, that intake of more than $18 \mathrm{~g}$ yarrow (Achillea millefolium) flower will exceed the ADI for thujone and that $7 \mathrm{~g}$ of woodruff (Galium odoratum) flower will exceed the TDI for coumarin (all for adults weighing $70 \mathrm{~kg})$.

Most often these levels will not be exceeded by using the plant as edible decoration or ornamentation of cakes or desserts. However, intake may be difficult to predict. Chefs and cook book writers have within the last decade shown much innovation and creativity when introducing new recipes with wild or cultivated plants. A Danish cookbook recently suggested use of flowers, leaves and immature seeds from garden nasturtium (Tropaeolum majus) in salads or as fillings in an omelette (Noack, 2017).

Even though occasional use of e.g. flowers of woodruff (Galium odoratum) seemingly does not exceed the TDI for coumarin, certain consumer groups (e.g. toddlers or heavy consumers of Chinese cinnamon (Cinnamomum cassia (L.)J.Presl.)) are highly exposed to coumarin from other food sources. Similar 
considerations apply to compounds such as erucic acid or thujone, which are also present in different food sources and thus a total exposure should be considered. In addition, subgroups of the population are sensitive to e.g. salicylic acid (found in heart's ease (Viola tricolor), coumarin (found in woodruff (Galium odoratum) or sparteine (found in common broom (Cytisus scoparius) due to genetic disorders, immune mechanisms, poor metabolism etc., and some of the compounds (e.g. tyramine, also found in common broom), can interact with prescription medications.

A genotoxic constituent, the benzoxazinoid DIBOA, was found in the flowers from yellow archangel (Lamium galeobdolon). Flowers from borage (Borago officinalis) and viper's bugloss (Echium vulgare) belonging to the family Boraginaceae contain genotoxic and carcinogenic 1,2-unsaturated pyrrolizidine alkaloids. However, phytochemical data on flowers from borage are highly variable. Flowers from common bugloss (Anchusa officinalis) belonging to the same family have not been analysed for content of 1,2-pyrrolizidine alkaloids but these substances have been detected in other plant parts. Exposure to compounds that are both genotoxic and carcinogenic are considered undesirable since there may be a risk associated with exposure even to low amounts, especially if consumed on a regular basis. Therefore it had been advised by risk assessors to reduce the exposure to such substances to a level that is as low as reasonably achievable (also known as the ALARA principle) (EFSA, 2005). Lycopsamine, found in some parts of common bugloss (Anchusa officinalis), is among the pyrrolizidine alkaloids EFSA recommends to screen for in food and food ingredients (EFSA, 2017).

\subsection{Novel food}

The decision on whether e.g. a flower is considered a well-known food, and is therefore not novel according to the novel food regulation, rely on documentation of a significant degree of consumption as food within member states of EU before 1997. Safety is presumed if there has been a significant use before 1997 and no safety concerns have been encountered. The same thoughts lay behind the possibility of easier access to the European market for traditional foods from third countries with the novel food regulation that came into force January 2018. Here a history of safe food use has to be documented by consumption in at least one third country for at least 25 years as a part of the customary diet of a significant number of people (EU regulation 2015/2283). A definition of 'history of safe use' based on an even longer exposure period is found 
in Knudsen et al. (2008). History of safe use for a food is here defined as 'a term for the qualified presumption of safety, where there is evidence for its safety from compositional data and from experience as an ongoing part of the diet for a number of generations in a large, genetically diverse population. This presumption is for a certain context of use (conditions of use, such as part of the plant used and required processing) and allows for minor population predispositions such as intolerance and allergenicity'.

It is the business operators that submit information to the food authorities on the human consumption to a significant degree of the food within the Union before 15 May 1997 eventually supported by other information available in Member States. Where there is no information on human consumption before 15 May 1997 or the information available is insufficient, a simple and transparent procedure, involving the Commission, the Member States and food business operators, should be established for collecting such information (EU regulation (EU) 2015/2283).

Looking into data provided by ethnobotanical surveys as done in this review may give useful information on food use. Most of the reviewed flowers have, however, not been commonly used for food prior to 1997 in Europe apart from borage (Borago officinalis) and garden nasturtium (Tropaeolum majus) (Pilegaard et al., 2007). Our data are supported by a recent observation of the large parts of flowers (including also a few cultivated ornamental species) used by ten top-chefs in Italy were not connected to the culinary folk traditions and/or food ethnobotanical literature in this country (Łuczaj, 2012).

These findings are in line with the very few or non-existent chemical data found for most of the flowers. It seems that limited or no food use goes hand in hand with limited interest in studying the chemical profile of the plant part. More chemical data existed for plants where the flowers had been used for other purposes e.g. flavouring of liquor or had been used for herbal medicine. An eventual use in food supplements may also have inspired for more chemical analysis but if a flower has only been used as an ingredient in food supplements such a limited use cannot be considered 'a significant degree of use as a food' according to the novel food regulation. The concept 'history of safe use' implies that the use have been recent so that eventual adverse effects have been encountered and had also had a realistic chance of being described e.g. in case reports in the scientific literature or as reported adverse effects to food authorities. For many of the flowers used, only a very limited historical food use was found. A use of flowers of lady's bedstraw (Galium 
verum) to coagulate milk in cheese manufacture in Denmark in the 1600-1700s may hardly be considered a history of safe food use or a significant food use before May 1997. However, it is up to the risk managers (national food authorities or EU Commission) to decide whether a use as food is significant enough to not being novel.

The only reviewed plant species that was found in the Novel Food Catalogue was yarrow (Achillea millefolium), which was considered novel for use as food. Some of the reviewed plants had previously been assessed and listed by the BVL regarding their use in food or food ingredients. The created list was designed to serve as a reference guide for authorities and food distributors. BLV has classified common broom (Cytisus scoparius) as 'not recommended for use in foods due to known risks' while borage (Borago officinalis), white dead nettle (Lamium album), woodruff (Galium odoratum) and heart's ease (Viola tricolor) were listed as 'substances only used in food and for which a dose restriction is required due to certain constituents'.

\subsection{Misidentifications}

A risk of mistaking the identity of picked flowers was identified for various plants within the family Apiaceae like wild carrot (Daucus carota) and cicely (Myrrhis odorata). Provided that people foraging wild plants either have botanical knowledge or carefully consult floras normally showing pictures of blooming plants, the risk of collecting the wrong plant is most likely smaller when picking flowers compared to e.g. collecting young leaves in spring where only few plant parts are visible for identification.

\subsection{Concluding remarks}

In conclusion, very little information on the safety of flowers from the campaign by the Danish Veterinary and Food Administration was available. We found, that of the 23 flowers reviewed, nine contained compounds with toxic or potentially toxic effect if eaten (Achillea millefolium, Borago officinalis, Echium vulgare, Cytisus scoparius, Lamium galeobdolon, Syringa vulgaris, Galium odoratum, Tropaeolum majus, Viola tricolor); two (Achillea millefolium) and (Calendula officinalis) contained unidentified toxic compound(s), and four (Anchusa officinalis, Alliaria petiolata, Lamium album, Lathyrus japonicus) were flowers from plants with potentially toxic compounds present in other plant parts or related species. Further, the food use of many of the flowers may be considered novel due to limited historical data on food use from ethnobotanical surveys. The 
inspections by the DVFA were conducted from May to October 2016 and thus seasonality could be an influencing factor. In addition, although the inspections were conducted nationwide, only 150 restaurants and local producers were visited and thus our findings may not be the full picture.

This review has revealed a strong need for better information on novel food status and safety of flowers picked from the wild or plants previously mainly cultivated e.g. for ornamental use, so that food producers, chefs and writers of cookbooks not only focus on taste, food texture, and beauty but also have a stronger attention on whether the flowers are safe to eat. 


\section{Acknowledgement}

This review is part of a project titled: 'Risk assessments of plants and other ingredients from the Danish nature used as food and scientific and popular communication of the results' funded by a grant from The Danish Agricultural Agency. 


\section{References}

Abbet, C., Mayor, R., Roguet, D., Spichiger, R., Hamburger, M., Potterat, O., 2014. Ethnobotanical survey on wild alpine food plants in Lower and Central Valais (Switzerland). J. Ethnopharmacol. 151, 624-634.

Abraham, K., Wohrlin, F., Lindtner, O., Heinemeyer, G., Lampen, A., 2010. Toxicology and risk assessment of coumarin: focus on human data. Mol. Nutr. Food. Res. 54, 228-239.

Abudayeh, Z.H.M., Al Azzam, K.M., Karpiuk, U.V., Hassouneh, L.K., Abuirmeileh, A., 2016. Isolation, identification, and quantification of lectin protein contents in Chamerion angustifolium L. dried raw material and the study of its activity using ratuserytroagglutination. Int. J. Pharm. Pharm. Sci. 8, 150-153.

Adebiyi, A., Adaikan, P.G., Prasad, R.N., 2004. Pregnancy outcomes following pre- and post-implantation exposure of Sprague-Dawley rats to benzyl isothiocyanate. Food Chem. Toxicol. 42, 715-720.

Akihisa, T., Yasukawa, K., Oinuma, H., Kasahara, Y., Yamanouchi, S., Takido, M., Kumaki, K., Tamura, T., 1996. Triterpene alcohols from the flowers of Compositae and their antiinflammatory effects. Phytochemistry 43, 1255-1260.

Alipieva, K., Evstatieva, L., Handjieva, N., Popova, S., 2003. Comparative analysis of the composition of flower volatiles from Lamium L. species and Lamiastrum galeobdolon Heist. ex Fabr. Z. Naturforsch. C 58, 779-782.

Alipieva, K., Kokubun, T., Taskova, R., Evstatieva, L., Handjieva, N., 2007. LC-ESI-MS analysis of iridoid glucosides in Lamium species. Biochem. Syst. Ecol. 35, 17-22.

Alipieva, K.I., Taskova, R.M., Jensen, S.R., Handjieva, N.V., 2006. Iridoid glucosides from Lamium album and Lamium maculatum (Lamiaceae). Biochem. Syst. Ecol. 34, 88-91.

Alvarez-Castellanos, P.P., Bishop, C.D., Pascual-Villalobos, M.J., 2001. Antifungal activity of the essential oil of flowerheads of garland chrysanthemum (Chrysanthemum coronarium) against agricultural pathogens. Phytochem. 57, 99-102.

Amberg-Müller, J., 2007. Pflanzen in Lebensmitteln - Aspekte der europaeischen bewertung. 4. BfR-Forum Verbraucherschutz.

http://www.bfr.bund.de/cm/343/pflanzen in lebensmitteln aspekte der europaeischen bewertung.pdf (accessed 24 November 2017).

Andrejak, M., Gersberg, M., Sgro, C., Decocq, G., Hamel, J.D., Morin, M., Gras, V., 1998. French pharmacovigilance survey evaluating the hepatic toxicity of coumarin. Pharmacoepidemiol. Drug Saf. 7 Suppl 1, S45-50.

Avula, B., Sagi, S., Wang, Y.-H., Zweigenbaum, J., Wang, M., Khan, I.A., 2015. Characterization and screening of pyrrolizidine alkaloids and $\mathrm{N}$-oxides from botanicals and dietary supplements using UHPLChigh resolution mass spectrometry. Food Chem. 178, 136-148.

Baert, N., Kim, J., Karonen, M., Salminen, J.-P., 2017. Inter-population and inter-organ distribution of the main polyphenolic compounds of Epilobium angustifolium. Phytochemistry 134, 54-63.

Behmanesh, Y., Abdollahi, M., 2002. Haemolysis after consumption of Viola tricolor. WHO Drug Information $16,15-16$.

Bejnarowicz, E.A., Smolenski, S.J., 1968. Gas chromatographic analysis of the essential oil from Achillea millefolium L. J. Pharm. Sci. 57, 2160-2161.

Berbecaru-lovan, A., Andrei, A.M., Nicolae, A.C., Stanciulescu, C.E., Berbecaru-lovan, S., Mogosanu, G.D., Pisoschi, C.G., 2016. Research concerning metabolic and antioxidant effects of the ethanolic extract from Syringae vulgaris flos f. Alba in streptozotocin-induced diabetic rats. Farmacia 64, 722-727.

Berbecaru-lovan, A., Stanciulescu, E.C., Berbecaru-lovan, S., Andrei, A.M., Ceausu, I., Pisoschi, C.G., 2014. Study regarding the antioxidant and antidiabetic activity of Syringae vulgaris flos $\mathrm{f}$. Violacea tincture in experimental diabetes. Farmacia 62, 1072-1081.

BfR, 2006a. Consumers, who eat a lot of cinnamon, currently have an overly high exposure to coumarin. Health Assessment No. 043/2006.

BfR, 2006b. High daily intakes of cinnamon: health risk cannot be ruled out. Health Assessment No. $044 / 2006$.

Bianco, A., Passacantilli, P., Righi, G., Nicoletti, M., Serafini, M., 1986. Iridoids in the flora of Italy; Part 11. 10-deoxymelittoside, an iridoid diglucoside, and other iridoids from Lamiastrum galeobdolon. Phytochemistry 25, 1981-1983.

Bird, G.W., Wingham, J., 1980. Lectins for polyagglutinable red cells: Cytisus scoparius, Spartium junceum and Vicia villosa. Clin. Lab. Haematol. 2, 21-23.

Blekkenhorst, L.C., Prince, R.L., Ward, N.C., Croft, K.D., Lewis, J.R., Devine, A., Shinde, S., Woodman, R.J., Hodgson, J.M., Bondonno, C.P., 2017. Development of a reference database for assessing dietary nitrate in vegetables. Mol. Nutr. Food Res. 61, 101. 
Boppré, M., Colegate, S.M., Edgar, J.A., 2005. Pyrrolizidine alkaloids of Echium vulgare honey found in pure pollen. J. Agric. Food Chem. 53, 594-600.

Broch-Due, Å.I., Aasen, A.J., Daasvatn, K., Forsgren, B., Gustafsson, J.-Å., Högberg, B., Becher, J., 1980. Alkaloids of Anchusa officinalis L.. Identification of the pyrrolizidine alkaloid lycopsamine. Acta Chem. Scand. 34b, 75-77.

Brøndegaard, V.J., 1987. Folk og Flora. Rosenkilde og Bagger, Denmark.

Buchmann, C.A., Nersesyan, A., Kopp, B., Schauberger, D., Darroudi, F., Grummt, T., Krupitza, G., Kundi, M., Schulte-Hermann, R., Knasmueller, S., 2007. Dihydroxy-7-methoxy-1,4-benzoxazin-3-one (DIMBOA) and 2,4-dihydroxy-1,4-benzoxazin-3-one (DIBOA), two naturally occurring benzoxazinones contained in sprouts of Gramineae are potent aneugens in human-derived liver cells (HepG2). Cancer Lett. 246, 290-299. Budzianowski, J., Skrzypczak, L., 1995. Phenylpropanoid esters from Lamium album flowers. Phytochemistry 38, 997-1001.

BVL, 2014. List of Substances of the Competent Federal Government and Federal State Authorities: Category" Plants and plant parts". Springer, Cham Heidelberg New York Dordrecht London.

Chandler, R.F., Hooper, S.N., Harvey, M.J., 1982. Ethnobotany and phytochemistry of yarrow, Achillea millefolium, Compositae. Economic Botany 36, 203-223.

Chavan, U.D., McKenzie, D.B., Amarowicz, R., Shahidi, F., 2003. Phytochemical components of beach pea (Lathyrus maritimus L.). Food Chem. 81, 61-71.

Cheeke, P.R., 1989. Toxicants of plant origin: Alkaloids, Volume I, 1 ed. CRC Press, Boca Raton, Florida.

Cipollini, D., Gruner, B., 2007. Cyanide in the chemical arsenal of garlic mustard, Alliaria petiolata. J. Chem. Ecol. 33, 85-94.

Cohn, D.F., Streifler, M., 1983. Intoxication by the chickling pea (Lathyrus sativus): nervous system and skeletal findings. Arch. Toxicol. Suppl. 6, 190-193.

Colombo, M.L., Assisi, F., Puppa, T.D., Moro, P., Sesana, F.M., Bissoli, M., Borghini, R., Perego, S., Galasso, G., Banfi, E., Davanzo, F., 2010. Most commonly plant exposures and intoxications from outdoor toxic plants. J Pharm. Sci. Res. 2, 417-425.

Cooper, M.R., Johnson, A.W., 1984. Poisonous plants in Britain and their effects on animals and man. HM Stationery Office, London.

Cox, D., O'Kennedy, R., Thornes, R.D., 1989. The rarity of liver toxicity in patients treated with coumarin (1,2-benzopyrone). Hum. Toxicol. 8, 501-506.

Cramer, L., Schiebel, H.-M., Ernst, L., Beuerle, T., 2013. Pyrrolizidine alkaloids in the food chain: development, validation, and application of a new HPLC-ESI-MS/MS sum parameter method. J. Agric. Food Chem. 61, 11382-11391.

Cunha, S.C., Faria, M.A., Sousa, T., Nunes, E., 2012. Isoflavone determination in spontaneous legumes identified by DNA barcodes. Food Chem. 134, 2262-2267.

Damtoft, S., 1992. Iridoid glucosides from Lamium album. Phytochemistry 31, 175-178.

Davison, C., Smith, P.K., Zimmerman, E.F., 1961. On the metabolism and toxicity of methyl salicylate. J. Pharmacol. Exp. Ther. 132, 207-211.

Della, A., Paraskeva-Hadjichambi, D., Hadjichambis, A.C., 2006. An ethnobotanical survey of wild edible plants of Paphos and Larnaca countryside of Cyprus. J. Ethnobiol. Ethnomed. 2, doi:10.1186/1746-4269$1182-1134$.

Dodson, C.D., Stermitz, F.R., 1986. Pyrrolizidine alkaloids from borage (Borago officinalis) seeds and flowers. J. Nat. Prod. 49, 727-728.

DVFA, 2017. Final report for the campaign: Planter, svampe m.m. i restauranter og hos lokale producenter. https://www.foedevarestyrelsen.dk/Kontrol/Kontrolkampagner/Kontrolkampagner-

2016/Sider/Kontrolkampagne-Brug-af-planter-og-svampe-i-restauranter.aspx (accessed 20 January 2018).

EFSA, 2004. Opinion of the Scientific Panel on Food Additives, Flavourings, Processing Aids and Materials in Contacts with Food (AFC) on a request from the Commission related to coumarin. EFSA J. 104, 1-36.

EFSA, 2005. Opinion of the Scientific Committee on a request from EFSA related to a harmonised approach for risk assessment of substances which are both genotoxic and carcinogenic. EFSA J. 282, 1-31.

EFSA, 2008a. Scientific Opinion on a request from the Commission on camphor in flavourings and other food ingredients with flavouring properties. EFSA J. 729, 1-15.

EFSA, 2008b. Scientific Opinion on coumarin in flavourings and other food ingredients with flavouring properties. EFSA J. 793, 1-15.

EFSA, 2011a. Scientific Opinion on pyrrolizidine alkaloids in food and feed. EFSA J. 9, 2406.

EFSA, 2011b. Scientific Opinion on risk based control of biogenic amine formation in fermented foods. EFSA J. 9, 2393. 
EFSA, 2016a. Acute health risks related to the presence of cyanogenic glycosides in raw apricot kernels and products derived from raw apricot kernels. EFSA J. 14, 4424.

EFSA, 2016b. Scientific Opinion on erucic acid in feed and food. EFSA J. 14, 173.

EFSA, 2017. Risks for human health related to the presence of pyrrolizidine alkaloids in honey, tea, herbal infusions and food supplements. EFSA J. 15, 4908.

El-Seedi, H.R., Azeem, M., Khalil, N.S., Sakr, H.H., Khalifa, S.A.M., Awang, K., Saeed, A., Farag, M.A., AlAjmi, M.F., Palsson, K., Borg-Karlson, A.-K., 2017. Essential oils of aromatic Egyptian plants repel nymphs of the tick Ixodes ricinus (Acari: Ixodidae). Exp. Appl. Acarol. 73, 139-157.

EMA, 2008a. EMA/HMPC/179281/2007 - Community herbal monograph on Calendula officinalis L., flos http://www.ema.europa.eu/docs/en GB/document library/Herbal -

Community herbal monograph/2009/12/WC500018121.pdf (accessed 5 July 2017).

EMA, 2008b. EMA/HMPC/179282/2007 - Assessment report for the development of community herbal monographs and for inclusion of herbal substance(s), preparation(s) or combinations thereof in the community list. Calendula officinalis flos. http://www.ema.europa.eu/docs/en GB/document library/Herbal -

HMPC assessment report/2011/10/WC500116274.pdf (accessed 5 July 2017).

EMA, 2010a. EMA/HMPC/131734/2009 - Community herbal monograph on Viola tricolor L. and/or subspecies Viola arvensis Murray (Gaud) and Viola vulgaris Koch (Oborny), herba cum flore. http://www.ema.europa.eu/docs/en GB/document library/Herbal -

Community herbal monograph/2011/01/WC500101197.pdf (accessed 5 July 2017).

EMA, 2010b. EMA/HMPC/131735/2009 - Assessment report on Viola tricolor L. and/or subspecies Viola arvensis Murray (Gaud) and Viola vulgaris Koch (Oborny), herba cum flore. http://www.ema.europa.eu/docs/en GB/document library/Herbal -

HMPC assessment report/2011/10/WC500116274.pdf (accessed 5 July 2017).

EMA, 2015. EMA/HMPC/712511/2014 - European Union herbal monograph on Epilobium angustifolium L. and/or Epilobium parviflorum herba. http://www.ema.europa.eu/docs/en GB/document library/Herbal -

Community herbal monograph/2015/04/WC500185271.pdf (accessed 5 July 2017).

Faurholdt, N., Lyshede, O., Schou, J., 2014. Giftige planter. BFN's forlag, Denmark.

Fernandes, L., Casal, S., Pereira, J.A., Saraiva, J.A., Ramalhosa, E., 2017. Edible flowers: A review of the nutritional, antioxidant, antimicrobial properties and effects on human health. J. Food Compost. Anal. 60, 3850.

Flamini, G., Cioni, P.L., Morelli, I., 2003. Differences in the fragrances of pollen, leaves, and floral parts of garland (Chrysanthemum coronarium) and composition of the essential oils from flowerheads and leaves. J. Agric. Food Chem. 51, 2267-2271.

Fossen, T., Slimestad, R., Ovstedal, D.O., Andersen, O.M., 2000. Covalent anthocyanin-flavonol complexes from flowers of chive, Allium schoenoprasum. Phytochemistry 54, 317-323.

Friedman, H., Vinokur, Y., Rot, I., Rodov, V., Goldman, G., Resnick, N., Hagiladi, A., Umiel, N., 2005. Tropaeolum majus L. as edible flowers: growth and postharvest handling. Advances in Horticultural Science 19, 3-8.

Frisch, T., Agerbirk, N., Davis, S., Cipollini, D., Olsen, C.E., Motawia, M.S., Bjarnholt, N., Moller, B.L., 2014. Glucosinolate-related glucosides in Alliaria petiolata: Sources of variation in the plant and different metabolism in an adapted specialist herbivore, Pieris rapae. J. Chem. Ecol. 40, 1063-1079.

Frohne, D., Pfänder, H.J., 1997. Giftpflanzen - Ein Handbuch für Apotheker, Ärzte, Toxikologen und Biologen. Wissenschaftliche Verlagsgesellschaft $\mathrm{mbH}$, Stuttgart.

Galloway, J.H., Farmer, K., Weeks, G.R., Marsh, I.D., Forrest, A.R.W., 1992. Potentially hazardous compound in a herbal slimming remedy. Lancet 340, 179-179.

Gasparotto, A., Jr., Boffo, M.A., Lourenco, E.L., Stefanello, M.E., Kassuya, C.A., Marques, M.C., 2009. Natriuretic and diuretic effects of Tropaeolum majus (Tropaeolaceae) in rats. J. Ethnopharmacol. 122, 517522.

Getahun, H., Mekonnen, A., TekleHaimanot, R., Lambein, F., 1999. Epidemic of neurolathyrism in Ethiopia. Lancet 354, 306-307.

Ghosh, D., 2013. A feast of flowers. Resonance 18, 1004-1014.

Gimenez-Roldan, S., Spencer, P.S., 2016. Azanon's disease. A 19th century epidemic of neurolathyrism in Spain. Rev. Neurol. (Paris) 172, 748-755.

Goffman, F.D., Thies, W., Velasco, L., 1999. Chemotaxonomic value of tocopherols in Brassicaceae. Phytochemistry 50, 793-798. 
Gomes, C., Lourenço, E.L., Liuti, E.B., Duque, A.O., Nihi, F., Lourenço, A.C., Mendes, T.C., Gasparotto, A., Jr., Dalsenter, P.R., 2012. Evaluation of subchronic toxicity of the hydroethanolic extract of Tropaeolum majus in Wistar rats. J. Ethnopharmacol. 142, 481-487.

Gonny, M., Bradesi, P., Casanova, J., 2004. Identification of the components of the essential oil from wild Corsican Daucus carota L. using C-13-NMR spectroscopy. Flavour Frag. J. 19, 424-433.

Gresser, G., Witte, L., Dedkov, V.P., Czygan, F.C., 1996. A survey of quinolizidine alkaloids and phenylethylamine tyramine in Cytisus scoparius (Leguminosae) from different origins. Z. Naturforsch. C 51, 791-801.

Grzeszczuk, M., Wesolowska, A., Jadczak, D., Jakubowska, B., 2011. Nutritional value of chive edible flowers. Acta Sci. Pol. Hortorum Cultus 10, 85-94.

Guarrera, P.M., Savo, V., 2016. Wild food plants used in traditional vegetable mixtures in Italy. J. Ethnopharmacol. 185, 202-234.

Guil-Guerrero, J.L., Giménez-Martínez, J.J., Torija-Isasa, M.E., 1999. Nutritional composition of wild edible Crucifer species. J. Food Biochem. 23, 283-294.

Hachey, J.-M., Collin, G.-J., Gagnon, M.-J., Simard, S., Dufour, S., Jean, F.-I., Vernin, G., Fraisse, D., 1990. Extraction and GC/MS analysis of the essential oil of Achillea millefolium L. complex (Compositae). J. Essent. Oil Res. 2, 317-326.

Haque, A., Hossain, M., Lambein, F., Bell, E.A., 1997. Evidence of osteolathyrism among patients suffering from neurolathyrism in Bangladesh. Nat. Toxins 5, 43-46.

Hashimoto, Y., Shudo, K., Okamoto, T., Nagao, M., Takahashi, Y., Sugimura, T., 1979. Mutagenicities of 4hydroxy-1,4-benzoxazinones naturally occurring in maize plants and of related compounds. Mutat. Res. 66, 191-194.

Hausen, B.M., Breuer, J., Weglewski, J., Rucker, G., 1991. $\alpha$-Peroxyachifolid and other new sensitizing sesquiterpene lactones from yarrow (Achillea millefolium L., Compositae). Contact Dermatitis 24, 274-280.

Hiermann, A., Bucar, F., 1997. Studies of Epilobium angustifolium extracts on growth of accessory sexual organs in rats. J. Ethnopharmacol. 55, 179-183.

Hiermann, A., Radl, B., 1998. Analysis of aromatic plant acids by capillary zone electrophoresis. J. Chromatogr. A 803, 311-314.

Höld, K.M., Sirisoma, N.S., Casida, J.E., 2001. Detoxification of $\alpha$ - and $\beta$-thujones (the active ingredients of absinthe): Site specificity and species differences in cytochrome P450 oxidation in vitro and in vivo. Chem. Res. Toxicol. 14, 589-595.

Höld, K.M., Sirisoma, N.S., Ikeda, T., Narahashi, T., Casida, J.E., 2000. a-Thujone (the active component of absinthe): $\gamma$-aminobutyric acid type A receptor modulation and metabolic detoxification. Proceedings of the National Academy of Sciences 97, 3826-3831.

Hussain, R.A., Poveda, L.J., Pezzuto, J.M., Soejarto, D.D., Kinghorn, A.D., 1990. Sweetening agents of plant origin phenylpropanoid constituents of seven sweet-tasting plants. Economic Botany 44.

IARC, 1993. Caffeic Acid. IARC Monogr. Eval. Carcinog. Risks Hum. 56, 115-134.

Il'ina, T.V., Kovaleva, A.M., Goryachaya, O.V., Aleksandrov, A.N., 2009. Essential oil from Galium verum flowers. Chem. Nat. Compd. 45, 587-588.

Ito, N., Nihei, T., Kakuda, R., Yaoita, Y., Kikuchi, M., 2006. Five new phenylethanoid glycosides from the whole plants of Lamium purpureum L. Chem. Pharm. Bull. (Tokyo) 54, 1705-1708.

Ivancheva, S., Kurteva, M., Stancheva, B., 2000. Dynamic and content of tannins and flavonoids in Achillea millefolium $\mathrm{L}$. and Tanacetum vulgare $\mathrm{L}$ [abstract]. Pharmacia 47, 17-20.

JECFA, 2002. Safety evaluation of certain food additives and contaminants hydroxyl- and alkoxy-substituted benzyl derivatives. http://www.inchem.org/documents/jecfa/jecmono/v48je15.htm\#1.5 (accessed 1 July 2017).

Jensen, H.A., Arnklit, F., Jensen, J., 2003. Anbefalede plantenavne. Gads Forlag, Copenhagen, Denmark. Justesen, U., Knuthsen, P., 2001. Composition of flavonoids in fresh herbs and calculation of flavonoid intake by use of herbs in traditional Danish dishes. Food Chem. 73, 245-250.

Keiser, H.R., Sjoerdsma, A., 1967. Studies on beta-aminopropionitrile in patients with scleroderma. Clin. Pharmacol. Ther. 8, 593-602.

Kelley, K.M., Behe, B.K., Biernbaum, J.A., Poff, K.L., 2001. Consumer ratings of edible flower quality, mix, and color. Horttechnology 11, 644-647.

Kempf, M., Heil, S., Hasslauer, I., Schmidt, L., von der Ohe, K., Theuring, C., Reinhard, A., Schreier, P., Beuerle, T., 2010. Pyrrolizidine alkaloids in pollen and pollen products. Mol. Nutr. Food Res. 54, 292-300.

Khalil, M., Raila, J., Ali, M., Islam, K.M.S., Schenk, R., Krause, J.-P., Schweigert, F.J., Rawel, H., 2012. Stability and bioavailability of lutein ester supplements from Tagetes flower prepared under food processing conditions. J. Funct. Foods 4, 602-610. 
Knudsen, I., Søborg, I., Eriksen, F.D., Pilegaard, K., Pedersen, J.W., 2008. Risk management and risk assessment of novel plant foods. Food Chem. Toxicol. 46, 1681-1705.

Kobets, T., Duan, J.-D., Brunnemann, K.D., Etter, S., Smith, B., Williams, G.M., 2016. Structure-activity relationships for DNA damage by alkenylbenzenes in turkey egg fetal liver. Toxicol. Sci. 150, 301-311.

Konami, Y., Yamamoto, K., Osawa, T., Irimura, T., 1992. The primary structure of the Cytisus scoparius seed lectin and a carbohydrate binding peptide. J. Biochem. 112, 366-375.

Kovacs, A., Simon-Sarkadi, L., Ganzler, K., 1999. Determination of biogenic amines by capillary electrophoresis. J. Chromatogr. A 836, 305-313.

Kremers, R.E., 1921. The chemistry of the volatile oil of milfoil. J. Am. Pharm. Assoc. Am. Pharm. Assoc. 10, 252-261.

Kubec, R., Svobodova, M., Velisek, J., 2000. Distribution of S-alk(en)ylcysteine sulfoxides in some Allium species. Identification of a new flavor precursor: S-ethylcysteine sulfoxide (ethiin). J. Agric. Food Chem. 48, 428-433.

Kucekova, Z., Mlcek, J., Humpolicek, P., Rop, O., 2013. Edible flowers - antioxidant activity and impact on cell viability. Cent. Eur. J. Biol. 8, 1023-1031.

Lachenmeier, D.W., Uebelacker, M., 2010. Risk assessment of thujone in foods and medicines containing sage and wormwood - Evidence for a need of regulatory changes? Regul. Toxicol. Pharmacol. 58, 437-443.

Lagarto, A., Bueno, V., Guerra, I., Valdes, O., Vega, Y., Torres, L., 2011. Acute and subchronic oral toxicities of Calendula officinalis extract in Wistar rats. Exp. Toxicol. Pathol. 63, 387-391.

Lara-Cortes, E., Osorio-Diaz, P., Jimenez-Aparicio, A., Bautista-Banos, S., 2013. Nutritional content, functional properties and conservation of edible flowers. Review. Arch. Latinoam. Nutr. 63, 197-208.

Laub, E., Olszowski, W.Z., 1982. Über den Cumaringehalt in Waldmeister und seine DC-Bestimmung. Lebensm. Unters. Forch. 179, 175-181.

Lewerenz, H.J., Bleyl, D.W., Plass, R., 1992. Subacute oral toxicity study of benzyl isothiocyanate in rats. Nahrung 36, 190-198.

Lim, T.K., 2014. Edible medicinal and non medicinal plants: Volume 8, flowers. Springer Netherlands.

Lopez-Garcia, J., Kucekova, Z., Humpolicek, P., Mlcek, J., Saha, P., 2013. Polyphenolic extracts of edible flowers incorporated onto atelocollagen matrices and their effect on cell viability. Molecules 18, 1343513445.

Loprinzi, C.L., Sloan, J., Kugler, J., 1997. Coumarin-induced hepatotoxicity. J. Clin. Oncol. 15, 3167-3168.

Lourenço, E.L.B., Lima Ribeiro, R.D.C., Araújo, V.D.O., Martino-Andrade, A.J., Dalsenter, P.R., Gasparotto, A., Jr., 2017. Fetopathies associated with exposure to angiotensin converting enzyme inhibitor from Tropaeolum majus L. Drug Chem. Toxicol. 40, 281-285.

Lourenço, E.L.B., Muller, J.C., Boareto, A.C., Gomes, C., Lourenço, A.C., Calloi Palozi, R.A., Lima Prando, T.B., Gasparotto, A., Jr., Dalsenter, P.R., 2014. Effects of angiotensin-converting enzyme inhibitor derived from Tropaeolum majus $\mathrm{L}$. in rat preimplantation embryos: Evidence for the dehydroepiandrosterone and estradiol role. eCAM 2014, 1-6.

Lourenço, E.L.B., Muller, J.C., Boareto, A.C., Gomes, C., Lourenço, A.C., Minatovicz, B., Crestani, S., Gasparotto, A., Jr., Martino-Andrade, A.J., Dalsenter, P.R., 2012. Screening for in vivo (anti)estrogenic and (anti)androgenic activities of Tropaeolum majus L. and its effect on uterine contractility. J. Ethnopharmacol. 141, 418-423.

Łuczaj, Ł., 2008. Archival data on wild food plants used in Poland in 1948. J. Ethnobiol. Ethnomed. 4, doi:10.1186/1746-4269-1184-1184.

Łuczaj, Ł., 2010. Changes in the utilization of wild green vegetables in Poland since the 19th century: A comparison of four ethnobotanical surveys. J. Ethnopharmacol. 128, 395-404.

Łuczaj, Ł., 2012. Ethnobotanical review of wild edible plants of Slovakia. Acta Societatis Botanicorum Poloniae 81, 245-255.

Łuczaj, Ł., Pieroni, A., Tardío, J., Pardo-de-Santayana, M., Sõukand, R., Svanberg, I., Kalle, R., 2012. Wild food plant use in 21 st century Europe, the disapperance of old traditions and the search for new ciusines involving wild edibles. Acta Societatis Botanicorum Poloniae 81, 359-370.

Łuczaj, Ł., Szymanski, W.M., 2007. Wild vascular plants gathered for consumption in the Polish countryside: a review. J. Ethnobiol. Ethnomed. 3, 17.

Lykkesfeldt, J., Moller, B.L., 1993. Synthesis of benzylglucosinolate in Tropaeolum majus L. (isothiocyanates as potent enzyme inhibitors). Plant Physiol. 102, 609-613.

Malakar, S., 2017. Bioactive food chemicals and gastrointestinal symptoms: a focus of salicylates. J. Gastroenterol. Hepatol. 32 Suppl 1, 73-77.

Malakar, S., Gibson, P.R., Barrett, J.S., Muir, J.G., 2017. Naturally occurring dietary salicylates: A closer look at common Australian foods. J. Food Compost. Anal. 57, 31-39. 
Marles, R., Durst, T., Kobaisy, M., Soucybreau, C., Abouzaid, M., Arnason, J.T., Kacew, S., Kanjanapothi, D., Rujjanawate, C., Meckes, M., Lozoya, X., 1995. Pharmacokinetics, metabolism and toxicity of the plantderived photoxin $\alpha$-terthienyl. Pharmacol. Toxicol. 77, 164-168.

Marongiu, B., Piras, A., Porcedda, S., Tuveri, E., Laconi, S., Deidda, D., Maxia, A., 2009. Chemical and biological comparisons on supercritical extracts of Tanacetum cinerariifolium (Trevir) Sch. Bip. with three related species of Chrysanthemums of Sardinia (Italy). Natural Product Research 23, 190-199.

Marotti, I., Marotti, M., Piccaglia, R., Nastri, A., Grandi, S., Dinelli, G., 2010. Thiophene occurrence in different Tagetes species: agricultural biomasses as sources of biocidal substances. J. Sci. Food Agric. 90, 1210-1217.

Martin, B., Bodson, M., 2010. Investigation on the morphological and chemical variability of sweet woodruff (Galium odoratum (L.) Scop.) in southern Belgium. Acta Horticulturae 860, 61-66.

Menendez-Baceta, G., Aceituno-Mata, L., Tardio, J., Reyes-Garcia, V., Pardo-de-Santayana, M., 2012. Wild edible plants traditionally gathered in Gorbeialdea (Biscay, Basque Country). Genetic Resources and Crop Evolution 59, 1329-1347.

Metzger, B.T., Barnes, D.M., 2009. Polyacetylene diversity and bioactivity in orange market and locally grown colored carrots (Daucus carota L.). J. Agric. Food Chem. 57, 11134-11139.

Mhamdi, B., Wannes, W.A., Dhiffi, W., Marzouk, B., 2009. Volatiles from leaves and flowers of borage (Borago officinalis L.). J. Essent. Oil Res. 21, 504-506.

Miguel, M., Barros, L., Pereira, C., Calhelha, R.C., Garcia, P.A., Angeles Castro, M., Santos-Buelga, C., Ferreira, I.C.F.R., 2016. Chemical characterization and bioactive properties of two aromatic plants: Calendula officinalis L. (flowers) and Mentha cervina L. (leaves). Food and Function 7, 2223-2232.

Mithril, C., Dragsted, L.O., 2012. Safety evaluation of some wild plants in the New Nordic Diet. Food Chem. Toxicol. 50, 4461-4467.

Mithril, C., Dragsted, L.O., Meyer, C., Blauert, E., Holt, M.K., Astrup, A., 2012. Guidelines for the New Nordic Diet. Public Health Nutr. 15, 1941-1947.

Mlcek, J., Rop, O., 2011. Fresh edible flowers of ornamental plants - A new source of nutraceutical foods. Trends in Food Science and Technology 22, 561-569.

Mølgaard, P., 2014. Giftige planter i naturen, i haven og på marken. Koustrup \& Co, Denmark.

Montanari, T., de Carvalho, J.E., Dolder, H., 1998. Antispermatogenic effect of Achillea millefolium L. in mice. Contraception 58, 309-313.

Morteza-Semnani, K., Saeedi, M., Akbarzadeh, M., 2016. Chemical composition of the essential oil of the flowering aerial parts of Lamium album L. J. Essent. Oil Bear. PI. 19, 773-777.

Mudge, E.M., Jones, A.M., Brown, P.N., 2015. Quantification of pyrrolizidine alkaloids in North American plants and honey by LC-MS: single laboratory validation. Food Addit. Contam. Part A Chem. Anal. Control Expo. Risk Assess. 32, 2068-2074.

Murakoshi, I., Yamashita, Y., Ohmiya, S., Otomasu, H., 1986. (-)-3- $\beta, 13-\alpha$-dihydroxylupanine from Cytisus scoparius. Phytochemistry 25, 521-524.

Nedelcheva, A., 2013. An ethnobotanical study of wild edible plants in Bulgaria. Eurasia. J. Biosci. 7, 77-94.

Nikolova, M., Asenov, A., 2006. Surface flavonoid aglycones in newly studied plant species. Natural Product Research 20, 103-106.

Noack, A., 2017. Fantasilater - eventyrlige blomstersalater. Koustrup \& Co., Denmark.

Nordic Council of Ministers, 2017. New Nordic Food. http://www.norden.org/en/theme/formerthemes/themes-2016/nordic-nutrition-recommendation/new-nordic-food/ (accessed 14 December 2017).

NTP, 2011. National Toxicology Program Technical Report No. 570: Toxicology and carcinogenesis studies of $\alpha, \beta$-thujone (CAS No. 76231-76-0) in F344/N rats and B6C3F1 mice (gavage studies). National Toxicology Program, November 2011, NTP TR 570, NIH publication no. 12-5912, National Institute of Health, U.S. Department of Health and Human Services. https://ntp.niehs.nih.gov/ntp/htdocs/lt rpts/tr570.pdf (accessed 22 november 2017).

Oh, S.Y., Shin, H.D., Kim, S.J., Hong, J., 2008. Rapid determination of floral aroma compounds of lilac blossom by fast gas chromatography combined with surface acoustic wave sensor. J. Chromatogr. A 1183, 170-178.

Olennikov, D.N., Kashchenko, N.I., 2014. Calendosides i-iv, new quercetin and isorhamnetin rhamnoglucosides from Calendula officinalis. Chem. Nat. Compd. 50, 633-637.

Olennikov, D.N., Kashchenko, N.I., Chirikova, N.K., Akobirshoeva, A., Zilfikarov, I.N., Vennos, C., 2017. Isorhamnetin and quercetin derivatives as anti-acetylcholinesterase principles of marigold (Calendula officinalis) flowers and preparations. Int. J. Mol. Sci. 18, doi:10.3390/ijms18081685. 
Pardo-de-Santayana, M., Tardío, J., Blanco, E., Carvalho, A.M., Lastra, J.J., San Miguel, E., Morales, R., 2007. Traditional knowledge of wild edible plants used in the northwest of the lberian Peninsula (Spain and Portugal): a comparative study. J. Ethnobiol. Ethnomed. 3, doi:10.1186/1746-4269-1183-1127.

Passalacqua, N.G., Guarrera, P.M., De Fine, G., 2007. Contribution to the knowledge of the folk plant medicine in Calabria region (Southern Italy). Fitoterapia 78, 52-68.

Pedersen, E., 1975. Pyrrolizidine alkaloids in Danish species of the family Boraginaceae. Arch. Pharm. Chem. Sci. Ed. 3, 55-64.

Pelkonen, O., Abass, K., Wiesner, J., 2013. Thujone and thujone-containing herbal medicinal and botanical products: Toxicological assessment. Regul. Toxicol. Pharmacol. 65, 100-107.

Pereira, O.R., Domingues, M.R.M., Silva, A.M.S., Cardoso, S.M., 2012. Phenolic constituents of Lamium album: Focus on isoscutellarein derivatives. Food Research International 48, 330-335.

Phillips, H., 1822. History of cultivated vegetables: comprising their botanical, medicinal, edible, and chemical qualities; natural history, and relation to art, science, and commerce. https://archive.org/details/historyofcultiva02phil (accessed 2 February 2018).

Pieroni, A., 1999. Gathered wild food plants in the upper valley of the Serchio river (Garfagnana), central Italy. Economic Botany 53, 327-341.

Pilegaard, K., Eriksen, F.D., Sørensen, M., Gry, J., 2007. EuroFIR-NETTOX plant list. European Food Information Resource Consortium (EuroFIR). Institute of Food Reseach, Norwich, UK.

Pilegaard, K., Eriksen, F.D., Sørensen, M., Gry, J., 2010. Information on plant foods in eBASIS: what is in a correct botanical scientific name? Eur. J. Clin. Nutr. 64, S108-S111.

Pilegaard, K., Gry, J., 2008. Alkaloids in edible lupin seeds. Temanord 605.

Radulovic, N., Dordevic, N., Stojanovic-Radic, Z., 2011. Volatiles of the Balkan endemic Daucus guttatus ssp zahariadii and cultivated and wild-growing D. carota - A comparison study. Food Chem. 125, 35-43.

Radwan, S.S., 1976. Localization of lipids containing (Z)-11-eicosenoic acid and (Z)-13-docosenoic acid in Tropaeolum majus. Phytochemistry 15, 1727-1729.

Ramos, A., Edreira, A., Vizoso, A., Betancourt, J., López, M., Décalo, M., 1998. Genotoxicity of an extract of Calendula officinalis L. J. Ethnopharmacol. 61, 49-55.

Ranfa, A., Maurizi, A., Romano, B., Bodesmo, M., 2014. The importance of traditional uses and nutraceutical aspects of some edible wild plants in human nutrition: the case of Umbria (central Italy). Plant Biosystems 148, 297-306.

Rattanachaikunsopon, P., Phumkhachorn, P., 2008. Diallyl sulfide content and antimicrobial activity against food-borne pathogenic bacteria of chives (Allium schoenoprasum). Bioscience, Biotechnology and Biochemistry 72, 2987-2991.

Rietjens, I.M.C.M., Cohen, S.M., Fukushima, S., Gooderham, N.J., Hecht, S., Marnett, L.J., Smith, R.L., Adams, T.B., Bastaki, M., Harman, C.G., Taylor, S.V., 2014. Impact of structural and metabolic variations on the toxicity and carcinogenicity of hydroxy- and alkoxy-substituted allyl- and propenylbenzenes. Chem. Res. Toxicol. 27, 1092-1103.

Roman, I., Rusu, M.A., Puică, C., Borşa, M., 2010. Citotoxic effects of three species of Epilobium (Onagraceae) herbal extracts in rats. Studia Universitatis Vasile Goldis Arad, Seria Stiintele Vietii 20, 19-23.

Rop, O., Mlcek, J., Jurikova, T., Neugebauerova, J., Vabkova, J., 2012. Edible flowers - a new promising source of mineral elements in human nutrition. Molecules 17, 6672-6683.

Ruan, J., Liao, C., Ye, Y., Lin, G., 2014. Lack of metabolic activation and predominant formation of an excreted metabolite of nontoxic platynecine-type pyrrolizidine alkaloids. Chem. Res. Toxicol. 27, 7-16.

Saadatian, M., Aghaei, M., Farahpour, M., Aghaei, M., 2017. Chemical compositions of flowers extract of Borage (Borago officinalis L.) in wild population from Urmia district, Iran. J. Essent. Oil Bear. PI. 20, 289-292.

Sabir, S.M., Khan, M.F., Rocha, J.B.T., Boligon, A.A., Athayde, M.L., 2015. Phenolic profile, antioxidant activities and genotoxic evaluations of Calendula officinalis. J. Food Biochem. 39, 316-324.

Santoro, A., Bianco, G., Picerno, P., Aquino, R.P., Autore, G., Marzocco, S., Gazzerro, P., Lioi, M.B., Bifulco, M., 2008. Verminoside- and verbascoside-induced genotoxicity on human lymphocytes: Involvement of PARP-1 and p53 proteins. Toxicol. Lett. 178, 71-76.

Santos-Cruz, L.F., Avila-Acevedo, J.G., Ortega-Capitaine, D., Ojeda-Duplancher, J.C., Perdigon-Moya, J.L., Hernandez-Portilla, L.B., Lopez-Dionicio, H., Duran-Diaz, A., Duenas-Garcia, I.E., Castaneda-Partida, L., Garcia-Bores, A.M., Heres-Pulido, M.E., 2012. Verbascoside is not genotoxic in the ST and HB crosses of the Drosophila wing spot test, and its constituent, caffeic acid, decreases the spontaneous mutation rate in the ST cross. Food Chem. Toxicol. 50, 1082-1090.

Savchenko, T., Blackford, M., Sarker, S.D., Dinan, L., 2001. Phytoecdysteroids from Lamium spp: Identification and distribution within plants. Biochem. Syst. Ecol. 29, 891-900. 
SCF, 2002. Opinion of the Scientific Commitee on Food on thujone. https://ec.europa.eu/food/sites/food/files/safety/docs/fs food-improvement-agents flavourings-out162.pdf (accessed 22 November 2017).

Schullehner, K., Dick, R., Vitzthum, F., Schwab, W., Brandt, W., Frey, M., Gierl, A., 2008. Benzoxazinoid biosynthesis in dicot plants. Phytochemistry 69, 2668-2677.

Senatore, F., Rigano, D., De Fusco, R., Bruno, M., 2004. Composition of the essential oil from flowerheads of Chrysanthemum coronarium L. (Asteraceae) growing wild in Southern Italy. Flavour Frag. J. 19, 149-152.

Silva, E.J., Costa-Silva, J.H., Evencio, L.B., Fraga Mdo, C., Coelho, M.C., Wanderley, A.G., 2009. Reproductive assessment of hydroalcohol extract of Calendula officinalis $L$. in Wistar rats. Phytother. Res. 23, $1392-1398$.

Silva, E.J.R., Goncalves, E.S., Aguiar, F., Evencio, L.B., Lyra, M.M.A., Coelho, M.-C.O.C., do Carmo, M., Fraga, C.A., Wanderley, A.G., 2007. Toxicological studies on hydroalcohol extract of Calendula officinalis L. Phytother. Res. 21, 332-336.

Simkova, K., Polesny, Z., 2015. Ethnobotanical review of wild edible plants used in the Czech Republic. J. Appl. Bot. Food Qual. 88, 49-67.

Sobolewska, D., Podolak, I., Makowska-Was, J., 2015. Allium ursinum: botanical, phytochemical and pharmacological overview. Phytochem. Rev. 14, 81-97.

Søborg, I., Andersson, C., Gry, J., 1996. Furocoumarins in plant foods - exposure, biological properties, risk assessment and recommendations. . Nordic Council of Ministers, Copenhagen.

Sõukand, R., Kalle, R., 2016. Changes in the use of wild food plants in Estonia: 18th-21st century. Springer, Cham.

Staniszewska, M., Kula, J., 2001. Composition of the essential oil from wild carrot umbels (Daucus carota L. ssp. carota) growing in Poland. J. Essent. Oil Res. 13, 439-441.

Staniszewska, M., Kula, J., Wieczorkiewicz, M., Kusewicz, D., 2005. Essential oils of wild and cultivated carrots - the chemical composition and antimicrobial activity. J. Essent. Oil Res. 17, 579-583.

Svanberg, I., 2012. The use of wild plants as food in pre-industrial Sweden. Acta Societatis Botanicorum Poloniae 81, 317-327.

Svanberg, I., Ægisson, S., 2012. Edible wild plant use in the Faroe Islands and Iceland. Acta Societatis Botanicorum Poloniae 81, 233-238.

Takzare, N., Hosseini, M.-J., Mortazavi, S.H., Safaie, S., Moradi, R., 2011. The effect of Achillea millefolium extract on spermatogenesis of male Wistar rats. Hum. Exp. Toxicol. 30, 328-334.

Tardío, J., Sánchez-Mata, M.d.C., Morales, R., Molina, M., García-Herrera, P., Morales, P., Díez-Marqués, C., Fernández-Ruiz, V., Cámara, M., Pardo-de-Santayana, M., Matallana-González, M.C., Ruiz-Rodríguez, B.M., Sánchez-Mata, D., Torija-Isasa, M.E., Guil-Guerrero, J.L., Boussalah, N., 2016. Ethnobotanical and food composition monographs of selected Mediterranean wild edible plants, in: M.d.C. Sánchez-Mata, J. Tardío (Eds.), Mediterranean Wild Edible Plants: Ethnobotany and Food Composition Tables. Springer, New York, pp. 273-470.

These, A., Bodi, D., Ronczka, S., Lahrssen-Wiederholt, M., Preiss-Weigert, A., 2013. Structural screening by multiple reaction monitoring as a new approach for tandem mass spectrometry: presented for the determination of pyrrolizidine alkaloids in plants. Anal. Bioanal. Chem. 405, 9375-9383.

Toth, G., Barabas, C., Toth, A., Kery, A., Beni, S., Boldizsar, I., Varga, E., Noszal, B., 2016. Characterization of antioxidant phenolics in Syringa vulgaris L. flowers and fruits by HPLC-DAD-ESI-MS. Biomed. Chromatogr. 30, 923-932.

Tunon, H., 1998. Alkaloids in Achillea millefolium L. - confusion in the literature. Compos. Newsl. 32, 1.

Wawzonek, S., Ponseti, I.V., Shepard, R.S., Wiedenmann, L.G., 1955. Epiphyseal plate lesions, degenerative arthritis, and dissecting aneurysm of the aorta produced by aminonitriles. Science 121, 63-65.

Webb, W.K., Hansen, W.H., 1963. Chronic and subacute toxicology and pathology of methyl salicylate in dogs, rats, and rabbits. Toxicol. Appl. Pharmacol. 5, 576-587.

WHO, 1995. Coumarin: a strong association with hepatotoxicity. WHO Drug Info 9, 159.

Xia, Q., Zhao, Y., Von Tungeln, L.S., Doerge, D.R., Lin, G., Cai, L., Fu, P.P., 2013. Pyrrolizidine alkaloidderived DNA Adducts as a common biological biomarker of pyrrolizidine alkaloid-induced tumorigenicity. Chem. Res. Toxicol. 26, 1384-1396.

Yalçin, F.N., Kaya, D., Çaliş, I., Ersöz, T., Palaska, E., 2008. Determination of iridoid glycosides from four Turkish Lamium species by HPLC-ESI/MS. Turk. J. Chem. 32, 457-467.

Yordanova, Z.P., Zhiponova, M.K., lakimova, E.T., Dimitrova, M.A., Kapchina-Toteva, V.M., 2014. Revealing the reviving secret of the white dead nettle (Lamium album L.). Phytochem. Rev. 13, 375-389.

Young, N.M., Watson, D.C., Williams, R.E., 1984. Structural differences between two lectins from Cytisus scoparius, both specific for D-galactose and N-acetyl-D-galactosamine. Biochem. J. 222, 41-48. 
Zanetti, G.D., Manfron, M.P., Da SM. Hoelzel, S., Pagliarin, V.P., Morel, A.F., 2003. Toxicidade aguda e atividade antibacteriana dos extratos de Tropaeolum majus L. Acta Farmacéutica Bonaerense 22, 159-162. 


\section{Highlights}

${ }^{*}$ Review of wild flowers used at restaurants shows a striking lack of safety data.

* 13 plants contained potential toxic compounds in the flowers or other plant parts.

* Limited historical data on food use from ethnobotanical surveys. 